\title{
Isotopic insights into diet and health at the site of Namu, Taumako Island, Southeast Solomon Islands
}

\author{
Rebecca L. Kinaston ${ }^{1,2}$ • Hallie R. Buckley ${ }^{2}$
}

Received: 8 April 2016/Accepted: 14 November 2016/Published online: 30 November 2016

(C) The Author(s) 2016. This article is published with open access at Springerlink.com

\begin{abstract}
A relatively new development to the milieu of archaeological techniques routinely used in the Pacific Island region, the stable isotope analysis of human skeletal and dental remains has provided important insights into diet, methods of subsistence and also intra-population variation in diet that may be related to age, sex or status. This study is a stable isotope analysis of one of the largest skeletal samples discovered in the Pacific Islands, from the Namu burial ground (ca. 700-300 BP) located on the small island of Taumako, Southeast Solomon Islands. Here, the stable isotope ratios of carbon and nitrogen of bone collagen $\left(n=142, \delta^{13} \mathrm{C}_{\text {bone }}\right.$ and $\left.\delta^{15} \mathrm{~N}_{\text {bone }}\right)$ and tooth dentine $(n=86$, $\delta^{13} \mathrm{C}_{\text {tooth }}$ and $\delta^{15} \mathrm{~N}_{\text {tooth }}$ ) are analysed to assess adult (survivor) and subadult (non-survivor) diets and patterns of breastfeeding, which also provided insight into possible maternal and foetal/ perinatal stress in the population. The $\delta^{13} \mathrm{C}_{\text {bone }}$ and $\delta^{15} \mathrm{~N}_{\text {bone }}$ results suggested that the adolescents and juveniles who died were eating foods from lower trophic levels than those who survived to adulthood, especially the males. The $\delta^{13} \mathrm{C}_{\text {tooth }}$ and $\delta^{15} \mathrm{~N}_{\text {tooth }}$ stable isotope values suggested that, during the ages of 5-9 years, individuals were eating more terrestrial and less marine foods than later in life as adults. The sex differences in adult diet $\left(\delta^{13} \mathrm{C}_{\text {bone }}\right.$ and $\delta^{15} \mathrm{~N}_{\text {bone values) were not present as }}$
\end{abstract}

Electronic supplementary material The online version of this article (doi:10.1007/s12520-016-0440-y) contains supplementary material, which is available to authorized users.

Rebecca L. Kinaston

rebecca.kinaston@otago.ac.nz

1 Department of Archaeogenetics, Max Planck Institute for the Science of Human History, Jena, Germany

2 Department of Anatomy, University of Otago School of Medical Sciences, Dunedin, New Zealand children $\left(\delta^{13} \mathrm{C}_{\text {tooth }}\right.$ and $\delta^{15} \mathrm{~N}_{\text {tooth }}$ values). The intra-population variation is discussed in the context of wider Pacific island diet and cultural processes and recent developments in understanding stress and disease processes on human stable isotope values.

Keywords Pacific islands · Stable isotope analysis . Palaeodiet $\cdot$ Subadult diet $\cdot$ Carbon $\cdot$ Nitrogen

\section{Introduction}

The Pacific Islands encompasses thousands of islands from New Guinea in the west to Micronesia in the north and Rapa Nui (Easter Island) in the east. The settlement history of the region is complex; the earliest evidence of human occupation can be found in New Guinea dating to 40,000 BP, and possibly earlier (Summerhayes et al. 2010). People associated with the Lapita culture arrived in the Bismarck Archipelago ca. 3400 BP and over the next 1000 years spread north, east and south, eventually settling the previously uninhabited islands of New Caledonia, Vanuatu, Fiji, Tonga and Samoa (Kirch 1997; Spriggs 1997; Summerhayes 2001). Subsequent expansion and settlement occurred in Polynesia and Micronesia, and the presence of a preColumbian Polynesian chicken bone (Gallus gallus) in Chile suggests that Polynesians reached South America ca. 1300 $1400 \mathrm{AD}$ (Storey et al. 2007). Over the past 20 years, bioarchaeology in the region has blossomed, providing insights to the health and past lifeways of Pacific Islanders (Bedford et al. 2011; Buckley et al. 2014; Buckley and Oxenham 2016; Buckley 2007; Buckley and Tayles 2003b; Buckley et al. 2010; Buckley et al. 2008; Douglas et al. 1997; Kinaston et al. 2016a, b; Littleton and Kinaston 2008; Pietrusewsky 2005; Pietrusewsky 2006; Pietrusewsky et al. 1997; Stantis et al. 2016b; Stodder et al. 2016). A growing number of stable isotope studies have successfully been used to understand specific 
cultural and economic aspects of these past societies, which has not been possible using other research methods, such as macroscopic analysis of human remains and archaeozoological assessments of subsistence (see review by Kinaston and Buckley 2013).

The first Pacific Island stable isotope studies for palaeodietary reconstruction were conducted on a number of human and faunal remains, along with modern fauna and flora, from a wide variety of sites (Davidson and Leach 2001; Leach et al. 1996; Leach et al. 2003), including one of the only Lapita burial grounds discovered at the time located on Watom Island, Papua New Guinea (Leach et al. 2000). The number of studies increased from the mid- $\mathrm{AD} 2000 \mathrm{~s}$ as researchers began realizing the potential of stable isotope analysis to provide direct evidence for diet in the past (Kinaston and Buckley 2013). In addition to discerning the palaeodiet at each site, these studies focussed on a range of more specific topics relevant to the region including adaptation to island environments (Ambrose et al. 1997; Commendador et al. 2013; Kinaston et al. 2016a, b; Kinaston et al. 2014b; Kinaston et al. 2013c), temporal changes in diet (Allen and Craig 2009; Commendador et al. 2013; Field et al. 2009; Jones and Quinn 2009; Kinaston et al. 2014a; Pate et al. 2001; Richards et al. 2009; Valentin et al. 2014; Valentin et al. 2011) and age-, sexand status-related variation in diet (Kinaston et al. 2013a; Kinaston et al. 2013b; Kinaston et al. 2009; Kinaston et al. 2014b; Stantis et al. 2015; Valentin et al. 2006).

As a result of poor post-mortem bone preservation in tropical environments, small excavation sizes, difficulty finding sites (especially in coastal areas) and cultural reasons for not excavating or for the immediate reburial after exhumation (mostly in Polynesia) (Turner-Walker 2008; Waldron 1994), the sample sizes for bioarchaeological investigations in the Pacific Islands, including stable isotope analyses, can be limited and may contain non-burial remains. As with most scientific research, a large sample size allows for intra-population comparisons using statistical analyses, which may provide a more nuanced understanding of certain aspects of a past community, such variation in diet that may be related to age, sex and status (Waldron 1994). Importantly, larger skeletal samples are also more likely to contain subadult individuals, the inclusion of whom results in a more accurate representation of the demography of the living population that the sample was derived from (Lewis 2007).

There is a paucity of stable isotope research focussed on subadult remains from the Pacific islands because of the abovementioned small size of the skeletal assemblages discovered in the region and, in some cases, the interment of subadult remains in areas other than the 'adult' burial ground (e.g. the Teouma site, Bedford et al. 2011; Bedford et al. 2010; Buckley et al. 2008). However, research focussed on subadult individuals can provide important information about past communities, as children are considered barometers of population health in bioarchaeological studies (Lewis 2007). The diets of infants and children would have had a direct impact on their health and ultimate survival (Lewis 2007). Therefore, understanding their diet through stable isotope analysis can provide insights into survivorship, adaptation and cultural processes in the past. A few notable studies have been conducted on Pacific island subadults including Kinaston et al. (2009), which focussed on foetal and perinatal stress in a Lapita population from Teouma, Vanuatu; Kinaston et al. (2013b) which included three subadults from a late prehistoric population from Papua New Guinea; Kinaston et al. (2014a) which analysed five subadults from a Lapita-age site on Uripiv island, Vanuatu, and Stantis et al. (2016a) which assessed 1 subadult and 16 adult and subadult teeth to assess childhood diet.

The current study is a stable isotope analysis of adult and subadult diet from one of the largest Pacific Island skeletal samples discovered to date $(n=226)$, the Namu burial ground on the island of Taumako in the Southeast Solomon Islands (Fig. 1). Carbon and nitrogen stable isotope ratios of bone collagen are used to address questions regarding age-related differences in diet at the site and the possible duration of breastfeeding. Additionally, carbon and nitrogen stable isotope ratios of tooth collagen of adults (the survivors of childhood) and of the bone and tooth collagen of infants and children (the non-survivors) are used to investigate possible dietary differences between these two groups and also assess if there were sex-related differences in diet during childhood. The carbon and nitrogen stable isotope values of adult female and foetal/infant co-interments are also assessed to further investigate the validity of using young subadults in palaeodietary studies.

\section{Materials and methods}

\section{The site and skeletal sample}

Taumako is a small (three miles long and one mile wide) volcanic island located in the Duff Island group in the far east of the Solomon Islands (Fig. 1) (Sheppard and Pavlish 1992). The Duff Islands themselves are part of a larger group of islands, the Santa Cruz Group (Leach and Davidson 2008). Taumako is home to one of 18 societies in the Western Pacific Islands known as Polynesian Outliers. These communities speak a Polynesian language and are thought to represent east-west 'blowback' movements from Polynesia into the Western Pacific (Kirch 1984). Archaeological evidence from Taumako supports that the island was first settled ca. 2700 BP by people associated with the Lapita Cultural Complex. Polynesian speakers arrived on Taumako possibly around the mid-second millennium $\mathrm{AD}$, but throughout the prehistoric sequence, there was considerable contact with other islands in the region (Kirch 1984; Leach and Davidson 2008).

The Namu burial site was excavated by Foss Leach and Janet Davidson in 1977 (Fig. 2). An initial aim of the excavation of the Namu burial ground was to analyse the remains of the people 
Fig. 1 The location of Taumako Island, Duff Islands Group, Southeast Solomon Islands (by Maximilian Dörrbecker https://commons.wikimedia. org/w/index php?curid=14481571)

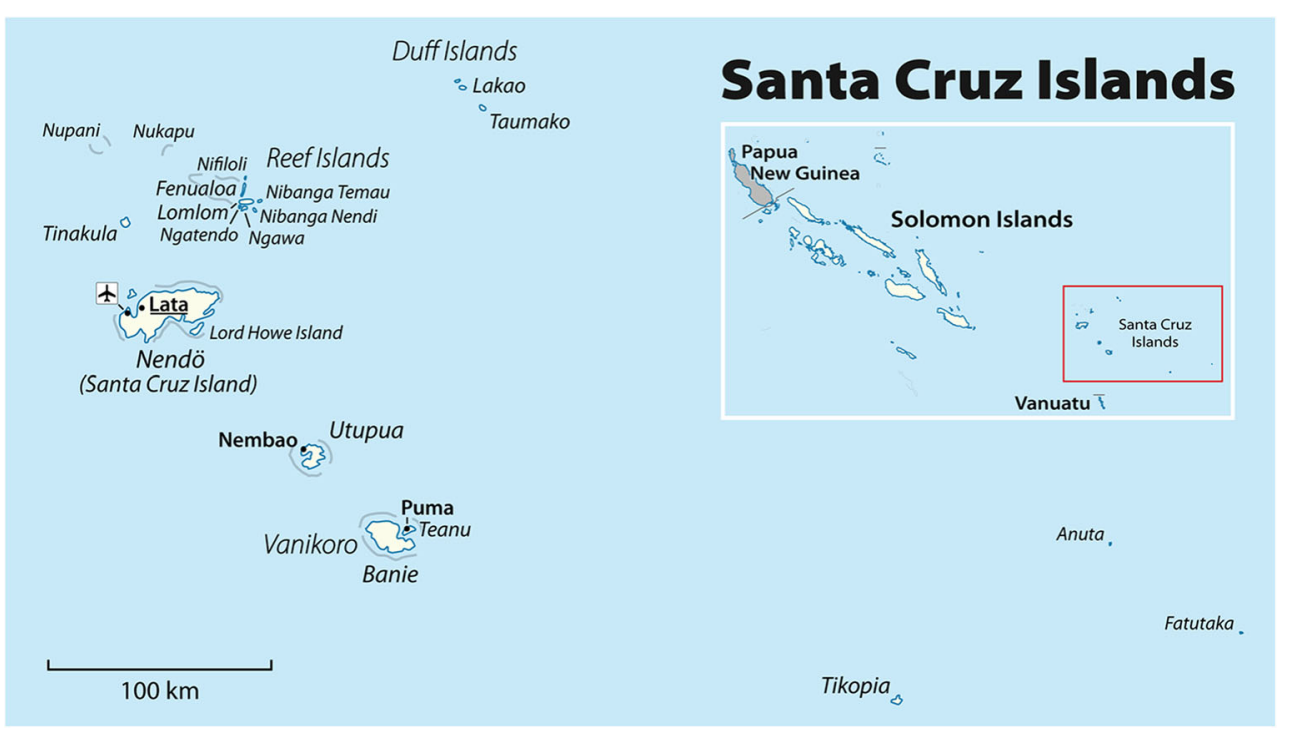

inhabiting a Polynesian Outlier in order to understand population affinities (Leach and Davidson 2008). The Namu site is composed of a low mound, $200 \mathrm{~m}$ inland from the ocean, $70 \mathrm{~cm}$ above the surrounding ground and $7-8 \mathrm{~m}$ in diameter.

Calibrated radiocarbon dates from six human bone samples suggest that the burial ground was in use from around 1220 to $1745 \mathrm{AD}$ at the maximum range, with a more conservative range of 1275 to $1655 \mathrm{AD}$ (Leach and Davidson 2008). The burial ground was intensively used during this time, and it has been suggested from the close proximity of the burials to one another that individuals were interred in family groups (Leach and Davidson 2008). In a number of instances $(n=7)$, either one or two subadult individuals were interred in the same grave as an adult female, possibly indicating a double or multiple burial of a mother with her child or relatives (J. Davidson personal comment). There were very few faunal remains discovered at the site, and these were unable to be analysed for the current analysis. The limited remains included three rat bones (likely Rattus praetor), fragments of marine turtle carapace, seven elasmobranch vertebrae and single or very few elements from the Coridae/

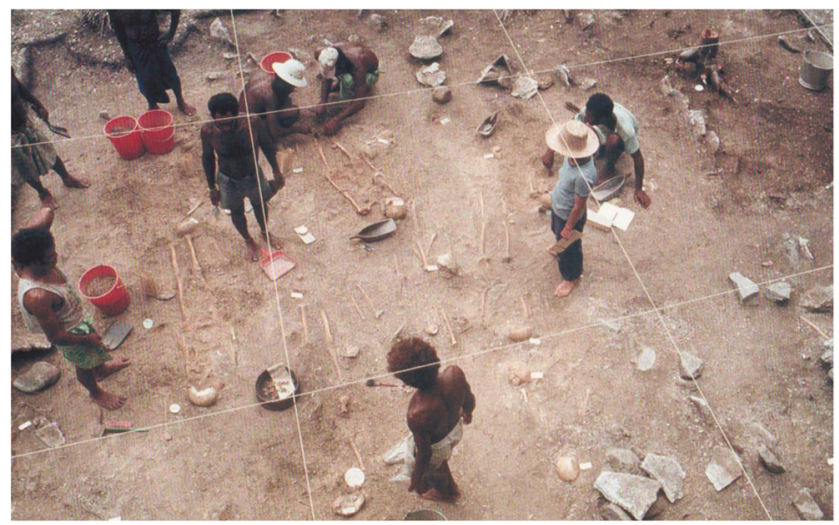

Fig. 2 Photo of the excavation of the Namu burial ground on Taumako (photo courtesy of Janet Davidson and Foss Leach)
Labridae fish family, Monotaxis grandoculis and unidentified teleost fish. Leach and Davidson (2008) suggested that these small bones might have been introduced to the site as charms rather than food debris. Material culture was found associated with some burials including shell money (kolokolo), large shell Tridacna discs (tavi), Conus discs, Nautilus discs, Nautilus rhomboid-shaped units, ivory reels and bobbles (associated with the coveted red-feather money used for bride price), Cassis knee ornaments, special amulets, worked flying fox teeth and shell nose ornaments (Davidson and Leach 1991; Leach and Davidson 2008). A previous isotopic study studied the diet of 99 adult individuals from the Namu burial ground and found dietary differences between males and females and high-status and low-status individuals, as inferred from burial wealth (Kinaston et al. 2013a).

An early report by Houghton identified 201 individuals in the Namu skeletal sample (published in Leach and Davidson 2008). A reanalysis by Buckley (2001), using standards from Buikstra and Ubelaker (1994), found 226 individuals, 133 of these representing adults (aged 17+ years), and these age and sex estimates are used in the current study of 149 individuals (See Online Resource 1). In this study, the ages of the subadult individuals were estimated using dental and skeletal development (Buikstra and Ubelaker 1994; Moorrees et al. 1963a; Moorrees et al. 1963b; Ubelaker 1989) and subsequently categorized into five age cohorts: foetal/perinatal (died before or around the time of birth), infant (0.1-1.0 year old), young child (1.1-5.0 years old), juvenile (5.1-9.0 years) and adolescent (9.1-16.9 years) (n.b. no children aged 3.1-5.0 years were found). The age categories were defined in such a way to be able to investigate infant and childhood diet, in addition to grouping the subadults whose biological ages matched those of the formation time of the first molar distal root tissue (formed between the ages of 5 and 9 years) that was sampled to understand the childhood diet of the adults and adolescents. 
Evidence of widespread treponemal disease, yaws (Treponema pertenue), was observed on the cranial and postcranial skeletons of a number of individuals buried in the Namu cemetery (Buckley and Dias 2002; Buckley and Tayles 2003a). Yaws is a chronic infectious disease that typically affects children. Without antibiotic treatment, yaws can persist throughout a person's life, beginning with skin lesions and culminating with diffuse osteoblastic bone production of (typically) the lower limbs, especially the tibia, in addition to the forearms, humeri, clavicle and crania. The tertiary phase of yaws affects adults and is characterized by destructive lytic lesions specific to treponemal disease known as gumma (Buckley and Tayles 2003b). As will be further discussed, the high prevalence of treponemal disease, and other pathogens such as malaria, affecting the Taumako skeletal sample may cause variation in the stable isotope values analysed from bone collagen, and therefore, the possible influence of yaws on bone collagen stable isotope values is also tested in this study.

\section{Stable isotope analysis}

Carbon stable isotope ratios $\left(\delta^{13} \mathrm{C}\right)$ are used to determine if certain types of plants with differing photosynthetic pathways were eaten $\left(\mathrm{C}_{3}, \mathrm{C}_{4}\right.$ and $\left.\mathrm{CAM}\right)$ and to assess marine vs. terrestrial food consumption patterns (Katzenberg 2008). This is because $\mathrm{C}_{4}$ plants and marine systems typically display higher $\delta^{13} \mathrm{C}$ values compared with $\mathrm{C}_{3}$ plants and terrestrial systems respectively. The $\delta^{13} \mathrm{C}$ values of CAM plants generally fall in between those of $C_{3}$ and $C_{4}$ plants (DeNiro and Epstein 1978; Schwarcz 1991). Dietary differences can be observed in bone collagen and bioapatite of humans and animals as carbon from the diet is used to synthesize bone and tooth tissue. The carbon stable isotope ratios of bone collagen in cortical bone are generally representative of dietary protein because this carbon is routed mainly from dietary amino acids (Froehle et al. 2010; Jim et al. 2004; Kellner and Schoeninger 2007). The $\delta^{13} \mathrm{C}$ values of bone apatite reflect the whole diet because carbon from all macronutrients (protein, lipids and carbohydrates) is utilized for its synthesis (Ambrose 1993; Ambrose and Norr 1993).

Bone collagen $\delta^{13} \mathrm{C}$ values are approximately $5 \%$ higher than the diet (diet-tissue spacing) if all dietary components are monoisotopic (e.g. all from a $\mathrm{C} 3$ terrestrial ecosystem), although the exact dietary offset $\left(\delta^{13} \mathrm{C}_{\text {diet-collagen }}\right)$ appears to be influenced by the isotopic composition of the dietary macronutrients (Ambrose and Norr 1993; Froehle et al. 2010; Tieszen and Fagre 1993). Trophic level enrichment of $\delta^{13} \mathrm{C}$ values has been found to be small, about $0-2 \%$, between consumer and prey collagen values (Bocherens and Drucker 2003).

Nitrogen stable isotope ratios $\left(\delta^{15} \mathrm{~N}\right)$ in bone collagen are only representative of the protein portion of the diet because other macronutrients (lipids and carbohydrates) do not contain nitrogen (Ambrose 1993). There is a stepwise enrichment in $\delta^{15} \mathrm{~N}$ values of $2-4 \%$ with each trophic step (Hedges and Reynard 2007). As a result, the $\delta^{15} \mathrm{~N}$ values of bone collagen are a reflection of the trophic position of an organism. The analysis of $\delta^{15} \mathrm{~N}$ values can help differentiate between the consumption of plants (lower values) and animals from higher trophic levels than plants (higher values). Both marine and freshwater aquatic systems display longer food chains and consequentially more trophic enrichment compared with terrestrial systems (DeNiro and Epstein 1981; Minagawa and Wada 1984). As a result of the trophic effect, breastfeeding results in the enrichment of infant tissues with ${ }^{15} \mathrm{~N}$ (Fogel et al. 1989; Fuller et al. 2006a; Katzenberg et al. 1996; Tsutaya and Yoneda 2015). The increase in $\delta^{15} \mathrm{~N}$ values of infant tissues (including bone collagen, tooth dentine and fingernails) and the subsequent decrease in these values when subadults are fed supplementary foods have been observed in numerous studies from around the world (Fuller et al. 2006a; Fuller et al. 2006b; Jay 2009; Jay et al. 2008; Nitsch et al. 2011; Prowse et al. 2008; Tsutaya and Yoneda 2015).

Used in conjunction with $\delta^{13} \mathrm{C}$ values, the analysis of $\delta^{15} \mathrm{~N}$ values can help discern between the consumption of marine (or freshwater) and terrestrial foods in the diet. Certain types of plants, such as legumes, and specific environments like mangroves and coral reefs have a prevalence of $\mathrm{N}_{2}$-fixing bacteria which act to lower the $\delta^{15} \mathrm{~N}$ values, which will be reflected in the tissues of higher consumers (Bashan and Holguin 2002; Keegan and DeNiro 1988; Schoeninger and DeNiro 1984; Yamamuro et al. 1995). Certain environmental factors, such as aridity (Heaton et al. 1986; Pate and Anson 2008; Schwarcz et al. 1999), and farming practices, especially the use of manure on crops (Bogaard et al. 2007; Fraser et al. 2011), may alter the $\delta^{15} \mathrm{~N}$ values of plants that form the base of the food web and should be considered if domesticated or wild faunal $\delta^{15} \mathrm{~N}$ values appear anomalous for a site where these situations may potentially occur.

The $\delta^{13} \mathrm{C}$ and $\delta^{15} \mathrm{~N}$ values of bone collagen from cortical bone are representative of approximately the last 10 years of the protein diet of an adult human (Hedges et al. 2007). As a result of elevated rates of bone modelling and remodelling in growing individuals, the $\delta^{13} \mathrm{C}$ and $\delta^{15} \mathrm{~N}$ values of bone collagen from infants and young children will be representative of a shorter dietary span (Waters-Rist and Katzenberg 2010). The $\delta^{13} \mathrm{C}$ and $\delta^{15} \mathrm{~N}$ values of tooth dentine are a reflection of the diet during the time of tissue formation (Beaumont et al. 2013).

As taphonomic processes and post-depositional disturbances can affect the isotopic integrity of a sample, it is important to be informed about the archaeological context in which it was found. Certain indicators can be used to assess the quality of collagen after purification. For carbon and nitrogen stable isotope ratios in collagen and tooth dentin, a C/N ratio of 2.9-3.6, a wt $\% \mathrm{C}$ above $30 \%$ and a $\mathrm{wt} \% \mathrm{~N}$ above $11 \%$ are indicative of well-preserved collagen (Ambrose 1993; 
DeNiro 1985; van Klinken 1999). Collagen yield has also been used as a collagen quality indicator, but the widespread use of ultrafilters to remove non-collagenous proteins and particles $<30 \mathrm{kDa}$ can reduce collagen yield by $50 \%$ or more (Müldner and Richards 2007).

\section{Methods}

Approximately $1.5 \mathrm{~g}$ of cortical bone from the long bones of the adults and long bones or ribs from subadults and the distal third of the root of the permanent first molar $(0.2-0.3 \mathrm{~g}$ measured from the cemento-enamel junction, formation time between the ages of 5 and 9 years, Moorrees et al. 1963a; Smith 1991) were sampled for the stable isotope analysis (See Online Resource 1). A modified Longin method (Longin 1971) was used to extract collagen from the bone and dentine samples at the University of Otago, Dunedin, New Zealand (Brown et al. 1988; Collins and Galley 1998). Bone samples were cleaned with aluminium oxide air abrasive equipment (Bego Easyblast). A Dremel ${ }^{\mathrm{TM}}$ drill fitted with a diamond edge saw was used to cut the distal half of the root of the first molar (measured from the cemento-enamel junction). Similar to Fuller et al. (2003), the dentine was sampled horizontally rather than along growth increment lines for the purposes of attaining enough sample to analyse. Secondary dentine was removed from inside the pulp cavity of the tooth root with a Dremel $^{\mathrm{TM}}$ drill fitted with a diamond burr. The samples of dentine were then sonicated for $5 \mathrm{~min}$ and fully dried.

All bone and dentine samples were soaked in $0.5 \mathrm{M} \mathrm{HCl}$ at $4{ }^{\circ} \mathrm{C}$ (changed every other day) until completely demineralized. The demineralized samples were then rinsed in deionized $\mathrm{H}_{2} \mathrm{O}$ until they reached a neutral $\mathrm{pH}$. The samples were gelatanized at $70{ }^{\circ} \mathrm{C}$ in a $\mathrm{pH} 3$ solution for $48 \mathrm{~h}$, followed by filtering with 5 8- $\mu \mathrm{m}$ Ezee® mesh filters (Elkay Laboratory Products) to remove any reflux-insoluble residues, and then ultrafiltered with Millipore Amicon Ultra 4 centrifugal filters (30,000 NMWL) to retain molecules larger than $30 \mathrm{kDa}$ (Jacobi et al. 2006). The purified 'collagen' was frozen and then lyophilized for $48 \mathrm{~h}$ and subsequently weighed into tin capsules before analysis by EAIRMS at Iso-Analytical (Cheshire, UK). Analytical error was routinely $\pm 0.1 \%$ o for $\delta^{13} \mathrm{C}$ and $\pm 0.2 \%$ ofor $\delta^{15} \mathrm{~N}$.

Levene's test for equality of variance was used before comparing means between two or more groups of data using parametric tests. Where there was no evidence of unequal variances $(p>0.05)$, two groups were analysed using a Student's $t$ test. If the variances were not equal $(p<0.05)$, the unequal variance $t$ test was used for the two groups.

There was evidence of widespread treponemal disease (yaws) within the cemetery sample (Buckley and Dias 2002; Buckley and Tayles 2003b), and, as yaws is a chronic disease, it is possible that the infection may have had an influence on the $\delta^{15} \mathrm{~N}$ values of individuals afflicted by the disease compared to the non-pathological individuals. Although only non- pathological bone was sampled for stable isotope analysis, adult individuals with 'probable' (gummatous lesions) and 'possible' (periostitis present on multiple limbs) lesions associated with treponemal disease (Table OR1) were still included in this study (Buckley and Tayles 2003b).

\section{Results}

Of the 146 bone samples and 92 tooth samples analysed in this study, four bone samples (burials 25, 36, 79 and 130) and six tooth samples (burials 73, 74, 84, 85, 87 and 195) did not reach the collagen quality indicators described above and were removed from the statistical analyses and interpretations (see Online Resource 1). One bone sample, from burial 1, displayed a $\% \mathrm{~N}$ of $10.9 \%(0.1 \%$ lower than the $11.0 \%$ cutoff $)$ but adequate other collagen quality indicators, and it was therefore included in the current study.

Descriptive statistics of the isotope results of the bone collagen and tooth dentine samples for each demographic group in the Taumako skeletal sample are presented in Table 1. Results for Spearman's correlation between $\delta^{13} \mathrm{C}_{\text {bone }}$ and $\delta^{15} \mathrm{~N}_{\text {bone }}$ values and between $\delta^{13} \mathrm{C}_{\text {tooth }}$ and $\delta^{15} \mathrm{~N}_{\text {tooth }}$ values are presented in Table 2.

The overall sample $(n=142)$ displayed average $\delta{ }^{13} \mathrm{C}_{\text {bone }}$ and $\delta^{15} \mathrm{~N}_{\text {bone }}$ values of $-16.5 \% \circ \pm 0.6$ and $11.6 \% \circ \pm 1.2$, respectively. When analysed by sex, males displayed similar $\delta^{13} \mathrm{C}_{\text {bone }}$ values to females but significantly higher $\delta^{15} \mathrm{~N}_{\text {bone }}$ values compared with females (diff. $0.4 \% o, p=0.027$ ) (Fig. 3).

There was less than a $0.3 \%$ difference between the average adult $\delta{ }^{13} \mathrm{C}_{\mathrm{bone}}$ value, the adolescent value, the juvenile value and the child value, but a slightly larger difference $0.5-0.6 \%$ o between the average adult $\delta^{13} \mathrm{C}_{\text {bone }}$ value and the infant and foetal/ perinatal value (Fig. 3). When all the subadults were pooled into one group, a significant difference was observed between adult

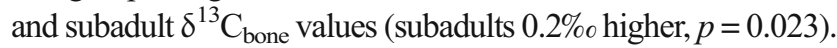
When the sexes were separated, the difference in adult and sub-

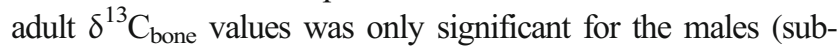
adults $0.2 \%$ higher, $p=0.048$ ) although the females also displayed a tendency for a difference in their $\delta^{13} \mathrm{C}_{\mathrm{bone}}$ values compared with that of the subadults (subadults $0.2 \%$ o higher, $p=0.057)$. In the instances where the sample size of the subadult subgroup allowed for statistical analysis ( $\geq 10$ individuals), significant differences were only observed between the $\delta^{13} \mathrm{C}_{\text {bone }}$ values of the adults and the infant group (infants $0.5 \%$ o higher, $p=0.010$ ), but not the child or adolescent groups. This same trend was observable when the female and male $\delta^{13} \mathrm{C}_{\text {bone values }}$ were compared with the $\delta^{13} \mathrm{C}_{\text {bone }}$ values of these three subadult groups, respectively (infant higher than female, diff. $0.5 \%$, $p=0.024$; infant higher than male, diff. $0.5 \% o, p=0.010$ ).

There was a larger range in the $\delta^{15} \mathrm{~N}_{\text {bone values (7.9-17.4\%o) }}$

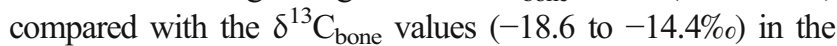
Taumako sample (Fig. 4). Although the average adult $\delta^{15} \mathrm{~N}_{\text {bone }}$ 
Table 1 Summary stable isotope information for the Taumako skeletal sample

\begin{tabular}{|c|c|c|c|c|c|c|c|c|c|c|}
\hline \multirow[t]{2}{*}{ Group $^{\mathrm{a}}$} & \multicolumn{5}{|c|}{ Bone collagen } & \multicolumn{5}{|c|}{ Tooth dentine } \\
\hline & $n$ & $\delta^{13} \mathrm{C}_{\text {bone }}$ & $\pm 1 \mathrm{SD}$ & $\delta^{15} \mathrm{~N}_{\text {bone }}$ & $\pm 1 \mathrm{SD}$ & $n$ & $\delta^{13} \mathrm{C}_{\text {tooth }}$ & $\pm 1 \mathrm{SD}$ & $\delta^{15} \mathrm{~N}_{\text {tooth }}$ & $\pm 1 \mathrm{SD}$ \\
\hline Young males & 24 & -16.3 & 0.4 & 11.6 & 0.8 & 22 & -16.6 & 0.6 & 11.4 & 0.7 \\
\hline Mid males & 9 & -16.7 & 0.6 & 11.7 & 0.9 & 9 & -16.6 & 0.3 & 11.4 & 0.4 \\
\hline Old males & 12 & -16.4 & 0.6 & 11.8 & 1.1 & 6 & -16.9 & 0.3 & 11.7 & 1.0 \\
\hline Total males & 45 & -16.4 & 0.5 & 11.7 & 0.9 & 37 & -16.7 & 0.5 & 11.4 & 0.7 \\
\hline Young females & 25 & -16.6 & 0.5 & 11.1 & 0.9 & 25 & -16.7 & 0.6 & 11.4 & 0.9 \\
\hline Mid females & 15 & -16.1 & 0.6 & 11.5 & 0.7 & 15 & -16.6 & 0.4 & 11.3 & 0.4 \\
\hline Old females & 9 & -16.6 & 0.8 & 11.3 & 1.3 & 5 & -16.6 & 0.1 & 11.3 & 0.7 \\
\hline Unknown age females & 1 & -16.5 & & 11.5 & & & & & & \\
\hline Total females & 50 & -16.4 & 0.6 & 11.3 & 0.9 & 45 & -16.7 & 0.5 & 11.3 & 0.7 \\
\hline Unknown sex mid age & 1 & -16.2 & & 11.8 & & 1 & -17.8 & & 10.2 & \\
\hline Total adults & 96 & -16.4 & 0.6 & 11.5 & 0.9 & 83 & -16.7 & 0.5 & 11.4 & 0.7 \\
\hline Adolescent (9.1-16.9 years) & 10 & -16.7 & 0.3 & 10.7 & 0.6 & 3 & -16.9 & 0.5 & 11.6 & 0.3 \\
\hline Juvenile (5.1-9.0 years) & 5 & -16.6 & 0.3 & 11.1 & 0.8 & & & & & \\
\hline Young child (1.1-5.0* years) & 14 & -16.3 & 0.7 & 12.6 & 1.7 & & & & & \\
\hline Infant (0.1-1 year) & 11 & -16.9 & 0.5 & 12.5 & 1.4 & & & & & \\
\hline Foetal/perinatal $(\leq 0)$ & 5 & -17.0 & 0.6 & 12.6 & 0.3 & & & & & \\
\hline Unknown subadult age & 1 & -17.0 & & 11.2 & & & & & & \\
\hline Total subadults & 46 & -16.6 & 0.6 & 12.0 & 1.5 & 3 & -16.9 & 0.5 & 11.6 & 0.3 \\
\hline Total sample & 142 & -16.5 & 0.6 & 11.6 & 1.2 & 86 & -16.7 & 0.5 & 11.4 & 0.7 \\
\hline
\end{tabular}

*no subadults aged 3.1-5.0 years were found

${ }^{\text {a }} Y A$ Young adult (17-34 years), MA Mid adult (35-49 years), OA Old adult (50 + years), UK unknown age

value was $0.8 \%$ o higher than the average adolescent value (and $0.4 \%$ o higher than the juvenile value), it was $\geq 1.0$ lower than the average young child, infant and foetal/perinatal $\delta^{15} \mathrm{~N}_{\text {bone }}$ values (Fig. 3). When all the subadults were pooled into one group, a significant difference was observed between adult and subadult $\delta^{15} \mathrm{~N}_{\text {bone }}$ values (subadults $0.5 \%$ o higher, $p=0.029$ ). When the sexes were separated, the differences in adult and subadult $\delta^{15} \mathrm{~N}_{\text {bone }}$ values were significant for the females (subadults $0.7 \%$ higher, $p=0.005$ ) but not the males (subadults $0.3 \%$ o higher). In the instances where the sample size of the subadult group allowed for statistical analysis ( $\geq 10$ individuals), significant differences were observed between the $\delta^{15} \mathrm{~N}_{\text {bone }}$ values of the adults and the infant group (infants $1.0 \%$ higher, $p=0.033$ ), the young child group (young child $1.1 \%$ higher, $p<0.001$ ) and the adolescent group (adolescent $0.8 \%$ lower, $p=0.002$ ). This trend was observable when the average female (infant $0.8 \%$ o higher, $p=0.024$; young child $1.3 \%$ o higher, $p<0.001$; adolescent $0.6 \%$ o lower, $p=0.018$ ) and male (infant $0.8 \%$ o higher,
Table 2 Spearman's correlation between $\delta^{13} \mathrm{C}_{\text {bone }}$ and $\delta^{15} \mathrm{~N}_{\text {bone }}$ values and $\delta^{13} \mathrm{C}_{\text {tooth }}$ and $\delta^{15} \mathrm{~N}_{\text {tooth }}$ values

\begin{tabular}{|c|c|c|c|c|c|c|}
\hline \multirow[t]{2}{*}{ Group } & \multicolumn{3}{|c|}{ Bone collagen } & \multirow[b]{2}{*}{$n$} & \multicolumn{2}{|c|}{ Tooth dentine } \\
\hline & $n$ & $r^{2}$ & $p$ & & $r^{2}$ & $p$ \\
\hline Males & 45 & 0.502 & $<0.001$ & 37 & 0.383 & 0.019 \\
\hline Females & 50 & 0.599 & $<0.001$ & 45 & 0.562 & $<0.001$ \\
\hline Total adults & $96^{\mathrm{a}}$ & 0.541 & $<0.001$ & 83 & 0.493 & $<0.001$ \\
\hline $9.1-16.9$ & 10 & -0.115 & 0.751 & 3 & N/A & N/A \\
\hline $5.1-9.0$ & 5 & N/A & N/A & 3 & N/A & N/A \\
\hline $1.1-5$ & 14 & 0.350 & 0.220 & & & \\
\hline $0-1$ & 11 & -0.264 & 0.433 & & & \\
\hline$<0$ & 5 & N/A & N/A & & & \\
\hline Total subadults & $46^{\mathrm{a}}$ & 0.058 & 0.702 & & & \\
\hline Total sample & $142^{\mathrm{a}}$ & 0.327 & $<0.001$ & 86 & 0.464 & $<0.001$ \\
\hline
\end{tabular}

${ }^{a}$ Total samples include unaged and unsexed individuals 
Fig. 3 Comparison of mean $( \pm 1$ SD) $\delta^{13} \mathrm{C}_{\text {bone }}$ and $\delta^{15} \mathrm{~N}_{\text {bone values }}$ plotted by age cohort and sex

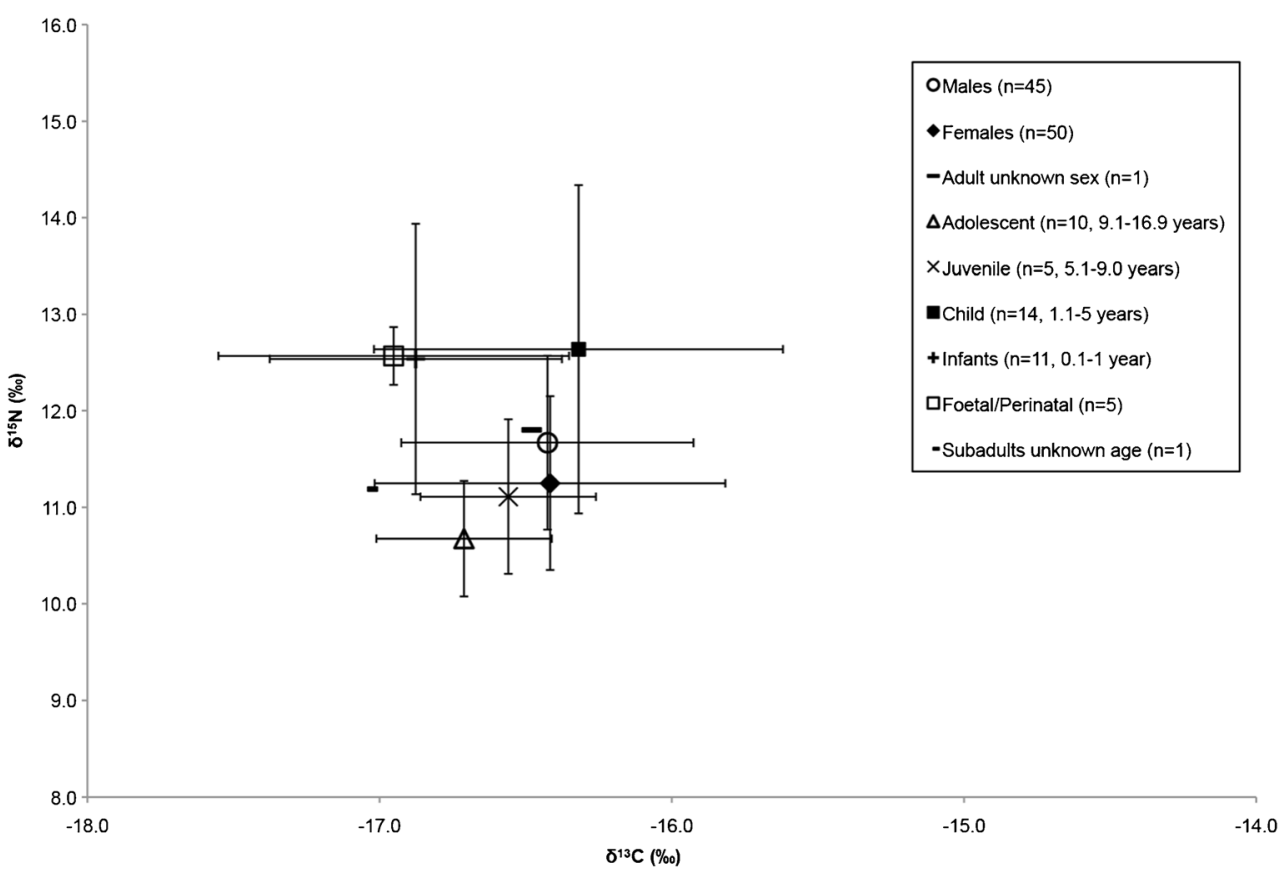

$p=0.016$; young child $0.9 \%$ o higher, $p=0.008$; adolescent $1.0 \%$ o lower, $p<0.001) \delta^{15} \mathrm{~N}_{\text {bone values were compared to those of }}$ each subadult subgroup.

Teeth were mainly sampled from adults $(n=83)$, but three adolescents were also sampled. The overall sample $(n=86)$ displayed a range in $\delta^{13} \mathrm{C}_{\text {tooth }}$ and $\delta^{15} \mathrm{~N}_{\text {tooth values of }-17.9 \text { to }}$ -15.0 and 9.8 to $14.0 \%$, respectively (Fig. 4). When analysed by sex, males displayed similar $\delta^{13} \mathrm{C}_{\text {tooth }}$ and $\delta^{15} \mathrm{~N}_{\text {tooth }}$ values with females. The adolescent $\delta^{13} \mathrm{C}_{\text {tooth }}$ values were slightly lower $\left(0.2 \%\right.$ ) and $\delta^{15} \mathrm{~N}_{\text {tooth values slightly higher }(0.2 \% \text { ) }}$ compared with the adult $\delta^{13} \mathrm{C}_{\text {tooth }}$ values.

A significant difference was observed between the $\delta^{13} \mathrm{C}_{\text {bone }}$ and $\delta^{13} \mathrm{C}_{\text {tooth }}$ values for all the adults (teeth $0.3 \%$ higher, $p=0.002$ ), the males (teeth $0.3 \%$ o higher, $p=0.034$ ) and the females (teeth $0.3 \%$ o higher, $p=0.048$ ). No significant differences were observed between the $\delta^{15} \mathrm{~N}_{\text {bone }}$ and $\delta{ }^{15} \mathrm{~N}_{\text {tooth }}$ values for the overall sample of adults (bone $0.1 \%$ higher), the males (bone $0.3 \%$ o higher) or the females (no difference). Overall, the average adult $\delta^{15} \mathrm{~N}_{\text {tooth }}$ value was $0.3 \%$ higher than the average $\delta^{15} \mathrm{~N}_{\text {bone }}$ value of the juveniles aged 5-9 years and the average adult $\delta^{13} \mathrm{C}_{\text {tooth }}$ value was $0.1 \%$ higher than

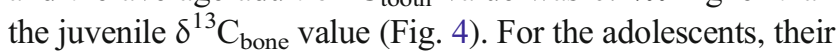
average $\delta^{13} \mathrm{C}$ tooth value was $0.2 \%$ lower than their average $\delta^{13} \mathrm{C}_{\text {bone }}$ value and their $\delta^{15} \mathrm{~N}_{\text {tooth }}$ value was $0.9 \%$ higher than their average $\delta^{15} \mathrm{~N}_{\text {bone }}$ value (Fig. 4).

To address this potential influence of treponemal disease on adult $\delta^{13} \mathrm{C}_{\text {bone }}$ and $\delta^{15} \mathrm{~N}_{\text {bone }}$ values, a regression equation was used to assess if there was evidence of a difference between the stable isotope values of adult individuals with possible and probable treponemal lesions and the other 'normal', non-pathological individuals. There was no evidence of an overall difference in $\delta^{13} \mathrm{C}_{\text {bone }}$ and $\delta^{15} \mathrm{~N}_{\text {bone }}$ values between the probable and possible pathological and non-diseased individuals.

\section{Discussion}

The diet of the adult, adolescent and juvenile individuals can be understood by comparing their $\delta^{13} \mathrm{C}_{\text {bone }}$ and $\delta^{15} \mathrm{~N}_{\text {bone }}$ values with a Pacific island dietary baseline developed from the isotopic ratios of modern plants and animals and prehistoric fauna (Fig. 5) (for a complete discussion of the dietary baseline, see Kinaston et al. 2014b). The average $\delta^{13} \mathrm{C}$ value $(-19.9 \%$ \pm 0.5$)$ of the fruit bat bones represents a purely $\mathrm{C}_{3}$ terrestrial-based diet, which corresponds with the $\delta^{13} \mathrm{C}$ value of $-20.0 \%$ o that other studies have reported as representing a $\mathrm{C}_{3}$ terrestrial-based diet in the Pacific islands (Richards et al. 2009; Valentin et al. 2006). Taking into account the trophic effect of $0-2 \%$ or the human $\delta^{13} \mathrm{C}_{\text {bone values and } 2-4 \% \text { for }}$ the $\delta^{15} \mathrm{~N}_{\text {bone }}$ values so the human bone collagen can be directly compared to the faunal bone collagen values, the protein portion of the human diet likely consisted of marine foods from reef and pelagic sources, including turtles and possibly seabirds, horticultural and arboricultural plant foods and terrestrial animals (most likely domesticated species) (Fig. 5). The significant positive correlation between the $\delta^{13} \mathrm{C}_{\text {bone }}$ and $\delta^{15} \mathrm{~N}_{\text {bone }}$ values supports this interpretation, and the differences between the individuals (from the adult, adolescent and juvenile age cohorts only) were likely a result of differing proportions of the same types of marine protein and lower trophic level terrestrial foods (such as starchy root vegetables 
Fig. 4 Box plots comparing the median (line), mean $(x)$,

minimum (lower error bar), and maximum (upper error bars)

$\delta^{15} \mathrm{~N}_{\text {bone }}$ and $\delta^{15} \mathrm{~N}_{\text {tooth }}$ values (a) and $\delta^{13} \mathrm{C}_{\text {bone }}$ and $\delta^{13} \mathrm{C}_{\text {tooth }}$ values (b) plotted by age cohort and sex a

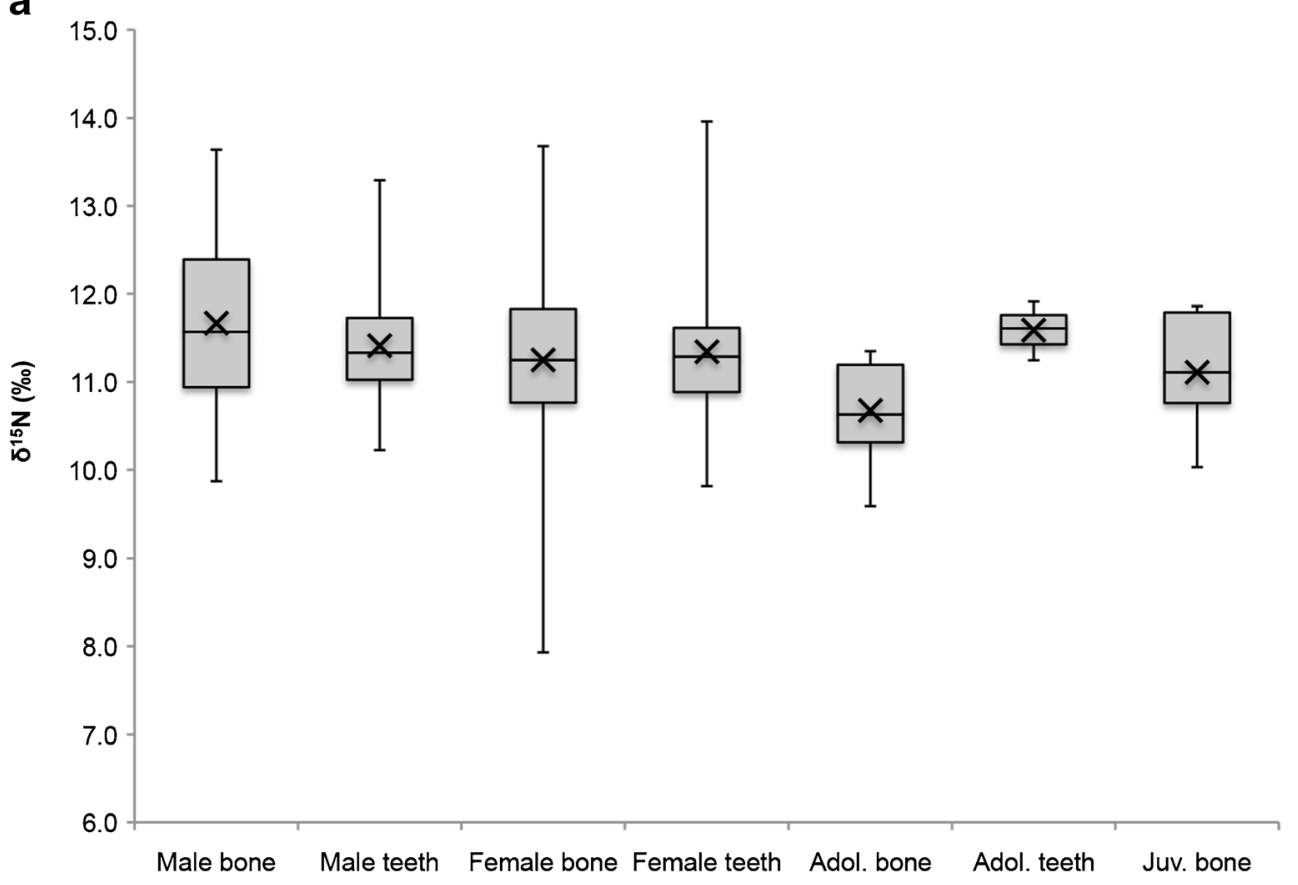

b

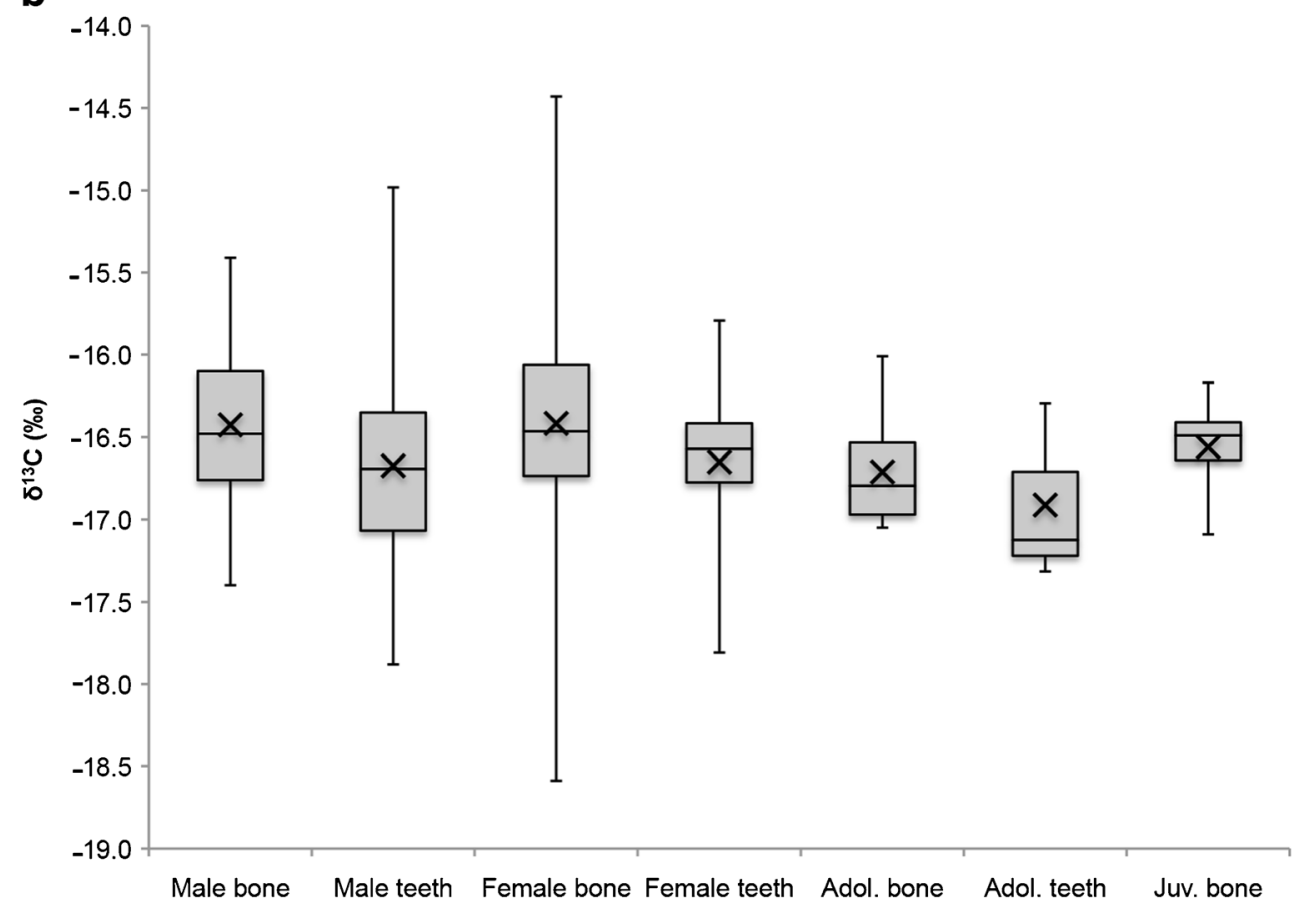

and nuts) (Kinaston et al. 2013a; Richards and Hedges 1999). These findings mirror those of the previous isotopic study of the adult individuals from Taumako, and a comprehensive discussion of diet on Taumako, including sex- and status-related differences, is presented in Kinaston et al. (2013a). The following interpretations will focus on the isotopic differences between the age groups and tissue types (bone and teeth) to provide a more nuanced understanding of age-related differences in diet at the site and information regarding survivorship and stress in the Taumako sample.

The significant difference observed between the male and

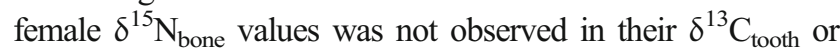
$\delta^{15} \mathrm{~N}_{\text {tooth }}$ values (Fig. 4). This pattern suggests that the variation in adult diet that exists between the sexes was not present during 


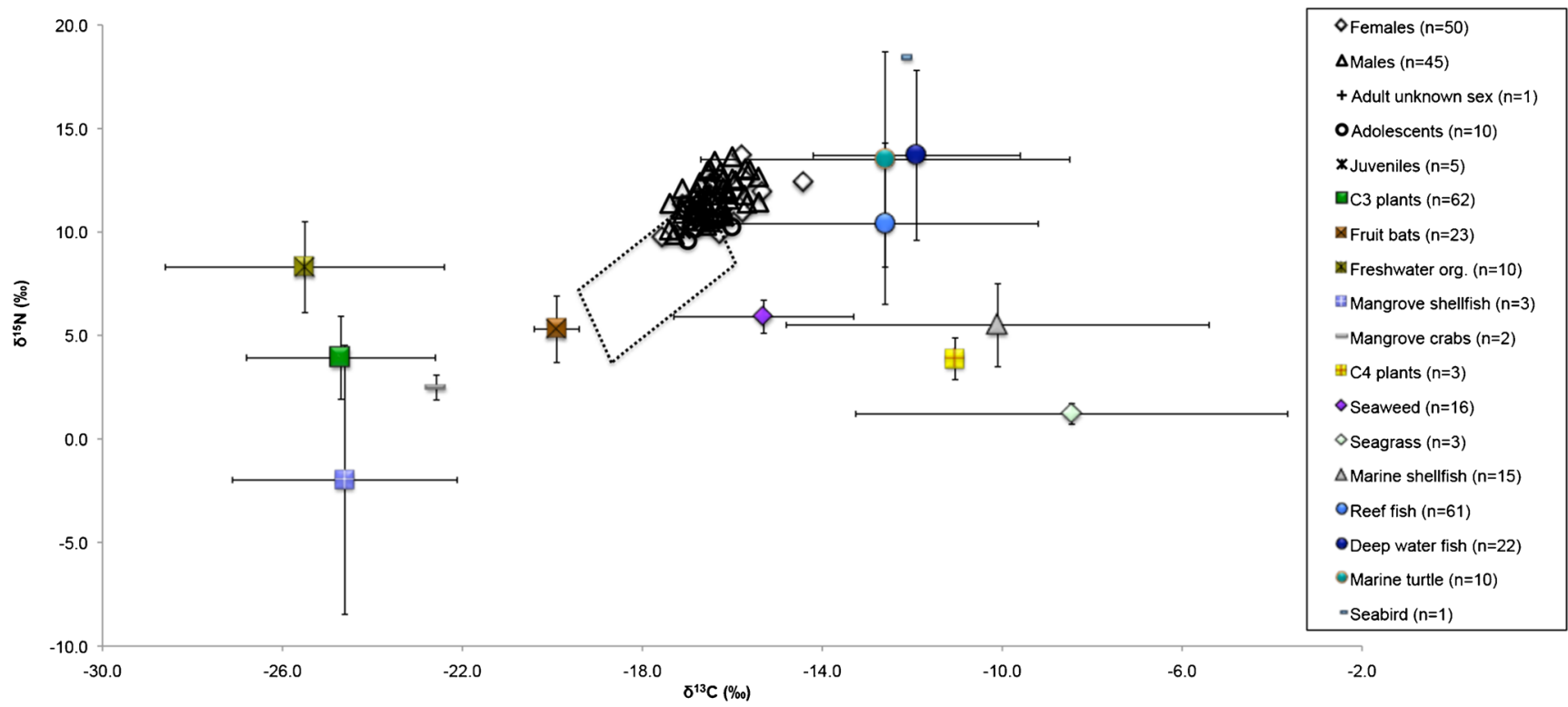

Fig. $5 \delta^{13} \mathrm{C}_{\text {bone }}$ and $\delta^{15} \mathrm{~N}_{\text {bone }}$ values of the Taumako individuals in reference to a Pacific Island dietary baseline (from Kinaston et al. 2014b). The dotted lines delineate the possible protein diet after correction for the trophic effect. The fruit bat bone collagen values represent a $100 \%$ terrestrial $\mathrm{C}_{3}$ diet

the time of tooth formation of the dentine samples (i.e. 5-9 years). The differences in bone and tooth stable isotope values may suggest that, during the ages of $5-9$ years, these individuals consumed slightly more terrestrial food and less marine and, possibly, less $\mathrm{C}_{4}$ plants than in their later lives.

The adolescent $\delta^{13} \mathrm{C}_{\text {bone }}$ and $\delta^{13} \mathrm{C}_{\text {tooth }}$ values follow a similar trend as the adults, but their $\delta^{15} \mathrm{~N}_{\text {tooth }}$ values were higher than their $\delta^{15} \mathrm{~N}_{\text {bone }}$ values. This pattern suggests that the diet of the adolescents changed from the time that they were juveniles, specifically that they were eating lower trophic level foods when they died. Alternatively, the higher adolescent $\delta^{15} \mathrm{~N}_{\text {tooth }}$ values coupled with low $\delta^{13} \mathrm{C}_{\text {tooth }}$ values may suggest that these individuals experienced some type of stress during the time of tooth development (discussed further below) and this may have affected their survival (Beaumont et al. 2015). The juvenile and the adolescent $\delta^{15} \mathrm{~N}_{\text {bone }}$ values were lower than the adult values, and this was statistically significant for the adolescent group (Figs. 3 and 4). The trend at Taumako suggests that the adolescent and to a lesser extent juvenile individuals ate protein from lower trophic levels than the adults, especially the males. This pattern may indicate that diet played a role in survivorship or possibly that unwell individuals may have been fed differently. Animal flesh, especially from turtle and pelagic species of fish, pig and chicken, is considered 'high-status' food in the Pacific islands. As discussed in detail in Kinaston et al. (2013a), the adult male individuals may have had more access to these higher-status foods compared to females and, with the addition of these new data, the juvenile and adolescent individuals at the site. Although there are usually set mealtimes, people (especially children) snack throughout the day in modern non-urban Pacific island communities (Barrau 1958; Barrau 1961; Kirch 2002; Oomen and Malcolm 1958). A higher proportion of lower trophic level foods foraged from the land and inshore environment for snacks, such as nuts, fruits, freshwater organisms, insects, shellfish, crustacea and seaweed, may have also influenced the observed values of the Taumako subadults.

In a palaeodietary study of a skeletal sample from Medieval Kulubnarti, Sudanese Nubia, Turner et al. (2007:18) suggested that variation in adult and subadult $\delta^{13} \mathrm{C}$ and $\delta^{15} \mathrm{~N}$ values 'could be attributed to a number of possible factors, including differential growth rates or stress episodes, differential dietary intake and variable levels of water stress'. The effect of potential water stress elevating the $\delta^{15} \mathrm{~N}$ values of any member of the sample can be ruled out at Taumako as the annual rainfall in the region is $5598 \mathrm{~mm}$ and the environment is extremely humid. With regard to the effect of growth on stable isotope values of subadults, Waters-Rist and Katzenberg (2010) analysed the $\delta^{15} \mathrm{~N}$ values of the diaphyses, metaphyses and epiphyses of a number of subadult individuals and found no significant differences between these areas of growing bones, thus supporting the suggestion that growth had no effect on $\delta^{15} \mathrm{~N}$ values. As will be discussed further below, increased stress and disease would likely result in higher, not lower, subadult $\delta^{15} \mathrm{~N}$ values (Beaumont et al. 2015; Katzenberg and Lovell 1999), and it is therefore suggested that age-related dietary variation is a likely reason for the difference observed between the adult, adolescent and juvenile $\delta^{15} \mathrm{~N}_{\text {bone }}$ values, rather than stress. The subadult individuals were the non-survivors and are therefore less representative of the living population than the adults. The possible dietary differences could actually represent the subsistence strategies, along with other factors affecting health, that 'failed' and subsequently affected the survivorship of these individuals (Turner et al. 2007). 
The $\delta^{13} \mathrm{C}_{\text {bone }}$ values of the foetal/perinatal, infant and, to a smaller extent, young child individuals were lower than the average adult female $\delta^{13} \mathrm{C}_{\text {bone }}$ value (Fig. 6). The trophic effect for $\delta^{13} \mathrm{C}$ values is suggested as $0-2 \%$, and therefore, the infants and young children that were breastfed should theoretically display elevated $\delta^{13} \mathrm{C}_{\text {bone }}$ values compared to the adult female mean. The elevated $\delta^{15} \mathrm{~N}_{\text {bone }}$ values of some of the infants and young children compared to the average female $\delta^{15} \mathrm{~N}_{\text {bone }}$ value, especially those outside the one standard deviation of the female mean, may be a result of the trophic effect of breastfeeding (Fuller et al. 2006a; Fuller et al. 2006b; Jay 2009) (Fig. 6). However, few infant or young child individuals fall outside the $2 \%$ o suggested as a low value for trophic level enrichment of ${ }^{15} \mathrm{~N}$ in bone collagen. The lack of 3.1 to 5-year-old individuals for comparison with these younger individuals means that it is impossible to determine if the $\delta^{15} \mathrm{~N}_{\text {bone }}$ value would be lower in this older subadult age cohort. There was a large range in $\delta^{13} \mathrm{C}_{\text {bone }}$ and $\delta^{15} \mathrm{~N}_{\text {bone }}$ values of the foetal/perinatal and young infant individuals compared to the adult female mean values. As a result of the observed variation in stable isotope values of the foetal/perinatal individuals and very young infants, in addition to the uneven demographic profile (i.e. lack of 3-5-year-olds) of the sample, it is difficult to estimate the duration of breastfeeding and the types of weaning foods for the Taumako sample based on the current data set. However, the large range in $\delta^{13} \mathrm{C}_{\text {bone }}$ and $\delta^{15} \mathrm{~N}_{\text {bone }}$ values of the foetal/perinatal and young infant individuals compared to the adult female mean values supports the suggestion that there are other possible explanations for the elevated young subadult $\delta^{15} \mathrm{~N}_{\text {bone }}$ values.
Fig. 6 Subadult $\delta^{15} \mathrm{~N}_{\text {bone }}$ (a) and $\delta^{13} \mathrm{C}_{\text {bone }}$ (b) values in reference to the adult female mean (solid line) $\pm 1 \mathrm{SD}$ (dashed line), in addition to low known values for the trophic effect $\left(2.0 \%\right.$ for $\delta^{15} \mathrm{~N}$ and $1.0 \%$ for $\delta^{13} \mathrm{C}$, dotted lines)

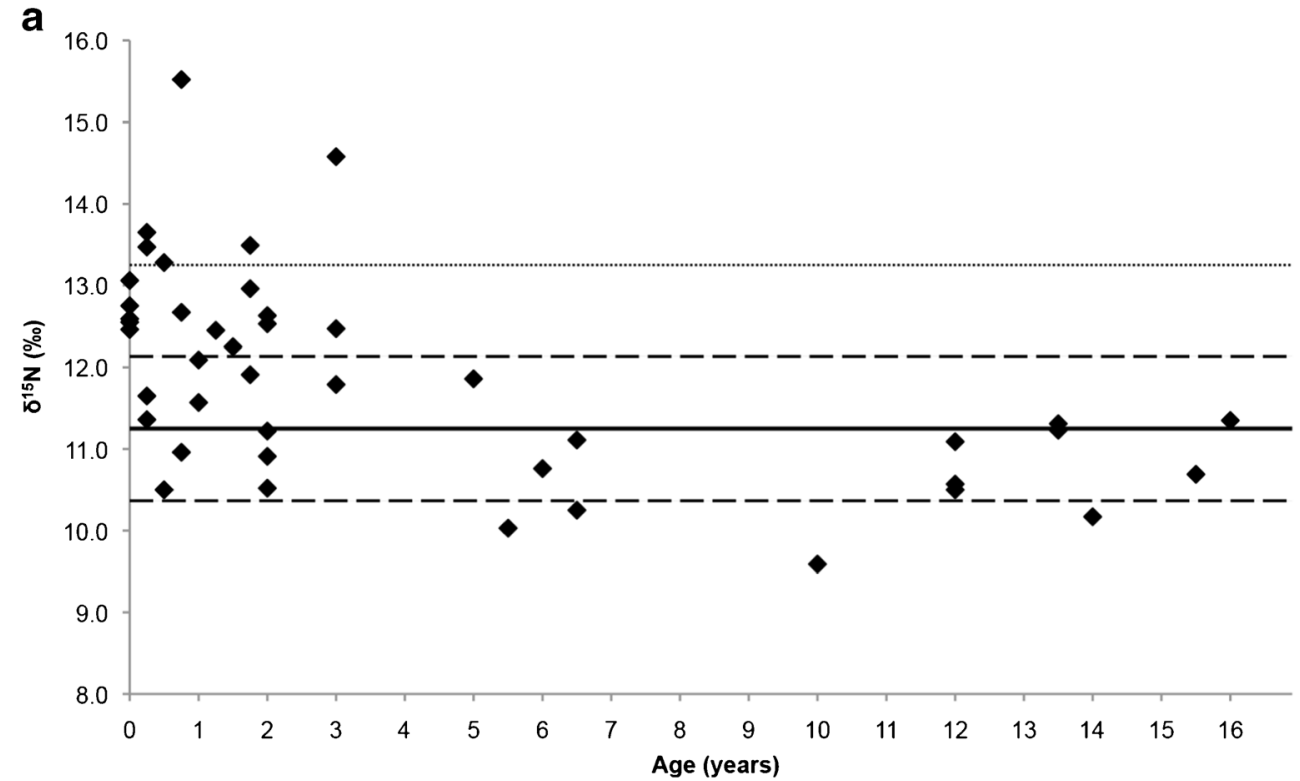

b

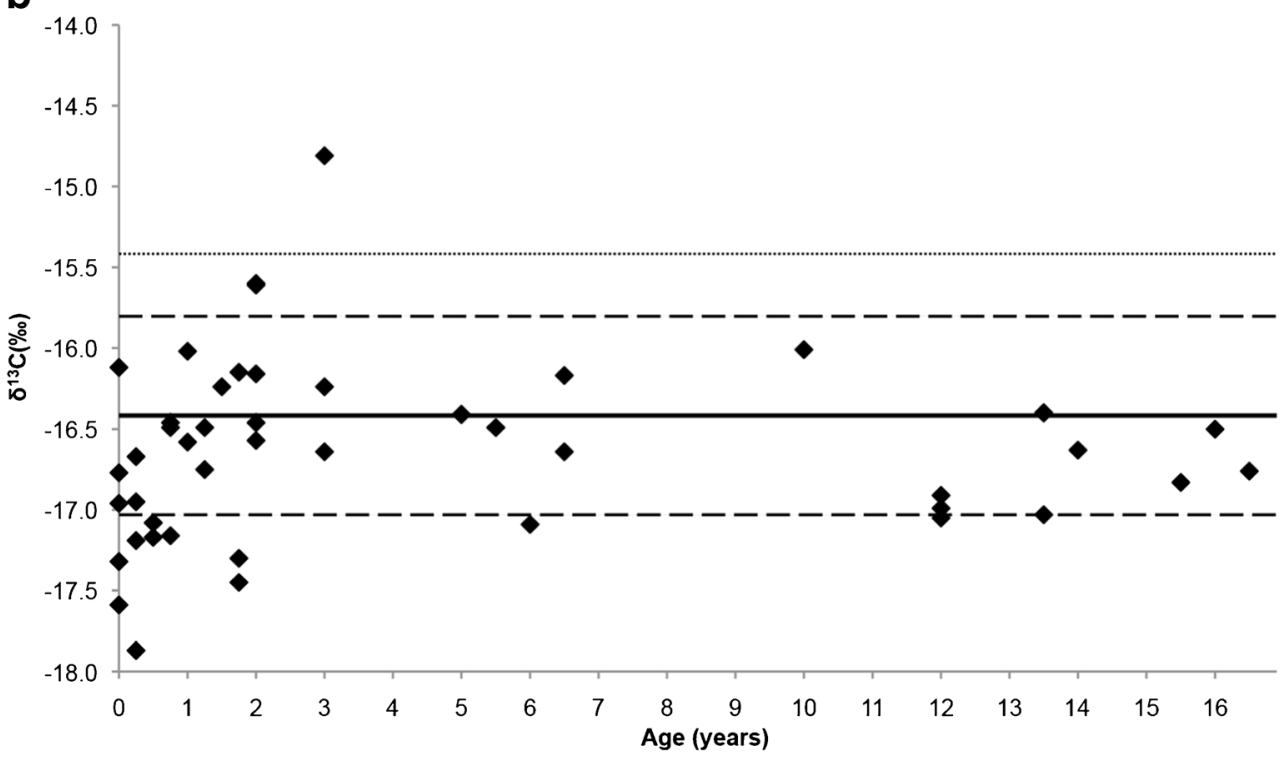


The fact that even the foetal/perinatal individuals displayed elevated $\delta^{15} \mathrm{~N}_{\text {bone }}$ values compared to the adult female mean (Fig. 6) may suggest that some other factors influenced their isotopic values as these very young individuals would not have had time to incorporate a breastfeeding signal in their tissues before death. A modern study of hair from mothers and their newborns showed a strong correlation between the $\delta^{15} \mathrm{~N}$ values of mother/infant hair, and the $\delta^{15} \mathrm{~N}$ and $\delta^{13} \mathrm{C}$ values of the infants' hair were statistically significantly higher than that of their mothers (de Luca et al. 2012). As such, the de Luca et al. (2012) study indicates that certain physiological effects of pregnancy may act to raise foetal tissue $\delta^{15} \mathrm{~N}$ and $\delta^{13} \mathrm{C}$ values, but it is unknown if this enrichment is applicable to bone collagen. A recent study conducted by Beaumont et al. (2015) found marked differences between the $\delta^{15} \mathrm{~N}$ and $\delta^{13} \mathrm{C}$ values of child and adult individuals from high-resolution samples of dentine. From these results, they suggested that stress and ill health during pregnancy and childhood may have affected the stable isotope values of the non-survivors. They concluded that the interpretation of breastfeeding patterns from bone collagen values (as attempted in this study) does not account for the complexities linked to the physiological status of pregnant mothers, their young offspring and the children in a sample population who died for unknown reasons. In our study, the low $\delta^{13} \mathrm{C}_{\text {bone values of the infant and }}$ young child individuals compared to the adult female mean could further support that the model used to investigate
Fig. $7 \quad \delta^{13} \mathrm{C}_{\text {bone }}$ (a) and $\delta^{15} \mathrm{~N}_{\text {bone }}$ (b) values for the adult female and subadult multiple and cointerments compared with the overall adult female mean stable isotope values (solid line) $\pm 1 \mathrm{SD}$ (dashed line)
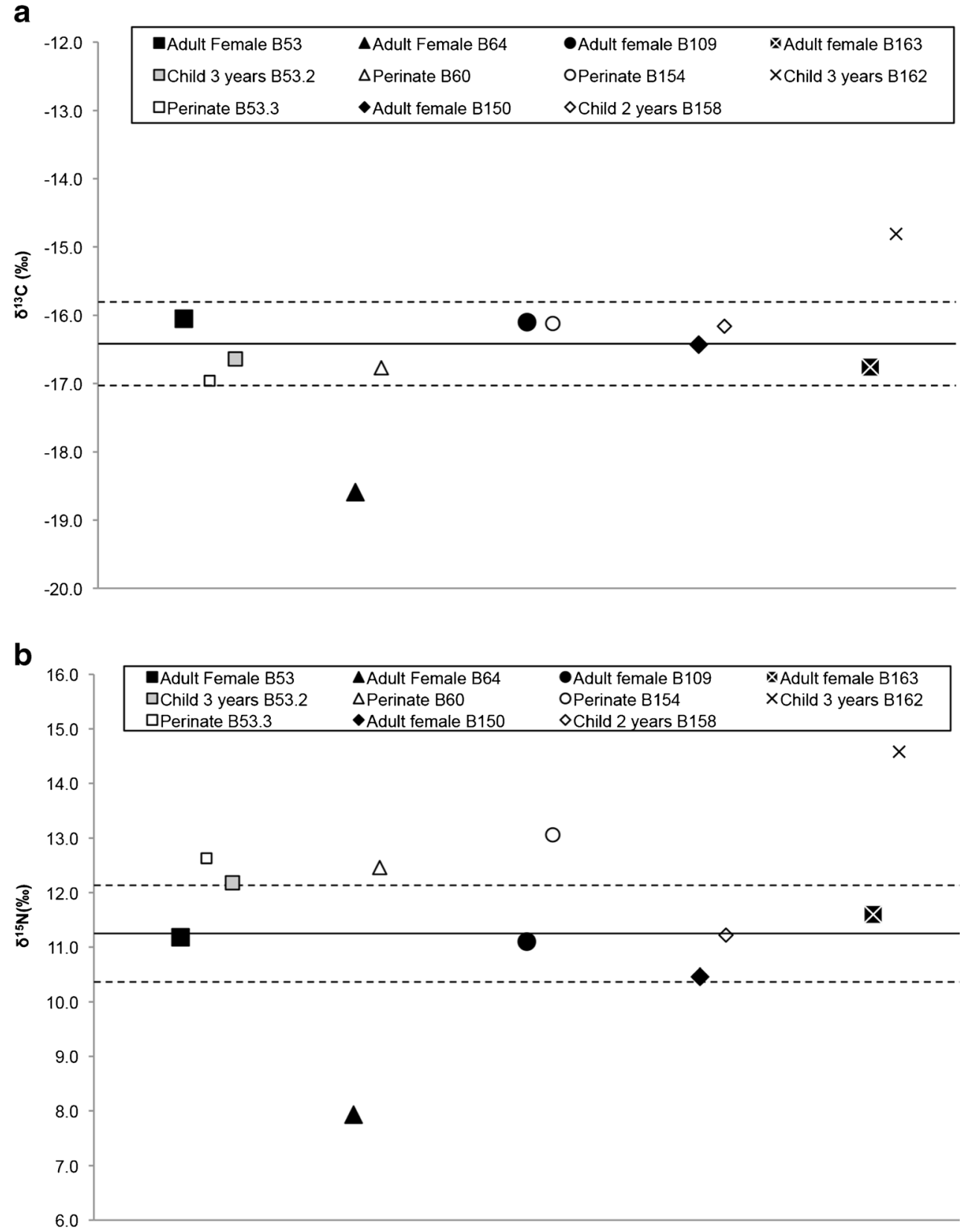
breastfeeding patterns in this study may not be correct. At the prehistoric Teouma site in Vanuatu, a similar trend was found (elevated foetal/perinatal $\delta^{15} \mathrm{~N}_{\text {bone }}$ values and lower $\delta^{13} \mathrm{C}_{\text {bone }}$ values compared with the adult female mean) and it was suggested that this pattern could be indicative of possible maternal ill health and in utero stress (Kinaston et al. 2009). The same pattern of elevated foetal/perinatal $\delta^{15} \mathrm{~N}_{\text {bone }}$ values can be observed when the adult female and subadult co-interments are compared (Fig. 7), although the $\delta^{13} \mathrm{C}_{\text {bone }}$ values of the foetal/perinatal individuals are more comparable with those of their co-interred adult female. As suggested by Beaumont et al. (2015), the foetal/ neonatal bone collagen could be an indicator of the mother's diet and physiology during the time of pregnancy. By comparing the stable isotope values of these foetal/neonatal individuals with the females' mean, the health and dietary of the pregnant mothers in a sample may possibly be assessed (Beaumont et al. 2015).

Taumako island is located in a region of high malaria endemicity, a pathogen known to cause significant ill health, particularly in pregnant women and young infants (Hendrickse 1987). Malaria and other pathogens are known to have influenced the expression of non-specific health indicators such as cribra orbitalia and dental enamel defects (Gowland and Western 2012). Both of these indicators of stress were found in high frequencies in the Taumako population in previous research, particularly affecting children in higher frequencies and with greater severity than adults (Buckley 2016; Buckley 2006). Another specific infectious disease that may have influenced in utero stress is widespread treponemal disease, yaws (T. pertenue) in the sample (Buckley 2016; Buckley and Tayles 2003a). Out of 44 individuals with cranial and postcranial lesions, 20 individuals $(45.5 \%)$ were diagnosed with probable treponemal disease based on the presence of gummatous lesions pathognomonic of the disease. A further six individuals were suggested as having possible treponemal disease based on the presence of osteoblastic lesions in the tibia and two other limb bones (Buckley and Tayles 2003b). Disease has been suggested as a possible cause of variation in $\delta^{15} \mathrm{~N}$ values, typically resulting in enrichment rather than depletion in ${ }^{15} \mathrm{~N}$ (Katzenberg 1999; Katzenberg and Lovell 1999; White and Armelagos 1997). This study found no differences between the $\delta^{13} \mathrm{C}_{\mathrm{bone}}$ and $\delta^{15} \mathrm{~N}_{\mathrm{bone}}$ values of the probable and possible pathological and nondiseased individuals. However, of the females who were represented in the multiple and co-interments, burials 53, 64 and 150 all displayed pathognomic lesions indicative of treponemal disease (i.e. probable yaws) and burial 109 was diagnosed with possible yaws following the criteria presented in Buckley and Tayles (2003b). The other female co-interment, burial 163 , did not display any periosteal lesions on her postcranial remains, but did display evidence for cribra orbitalia, a non-specific indicator of stress (Buckley 2016). All but one (burial 60) of the subadult co-interments also displayed evidence of stress in the form of endocranial new bone formation (burials 53.2 and 162), cribra orbitalia (burials 53.3 and 162) and periosteal reactions on the post-cranial bones (154 and 158)(Fig. 7). It is possible that the treponemal disease of three, possibly four, of the females and other, as yet unidentified stressors (e.g. malaria, hookworm), may have negatively affected the health of their foetus (as evidenced from the non-specific indicators of stress) and the ultimate survival of their offspring. The high pathogen loads affecting the health of the population, as expressed in the skeletal record, may have affected the higher $\delta^{15} \mathrm{~N}$ values of the subadult multiple and co-interments and other young individuals in the sample.

\section{Conclusions}

Stable isotope analysis has provided an avenue to address specific questions about the lives of people who were interred in the Namu burial ground on Taumako. There were few faunal remains excavated from the Namu burial ground, and no other methods, such as microfossil or palynological analyses, were previously used to try to ascertain dietary patterns at the site. The isotopic analyses performed here have offered a way to understand the diet of the population interred in the Namu burial ground, and because this method uses the individual as the unit of analysis, more nuanced information regarding the childhood diet of the adults (the survivors) and subadults (the non-survivors) and its potential effect on survivorship could be better understood. It was found that juveniles and adolescents who did not survive were eating foods from lower trophic levels than the adults, especially the males, and this may have affected their survival. The difference in diet found between the adult males and females were not observed when these individuals' teeth were analysed, indicating that the consumption of higher trophic level foods known to be more 'valuable' in the Pacific (i.e. meat and fish) by males started sometime after the formation of the distal half of the first molar (after 9 years old) and has highlighted a hitherto unknown change in dietary patterns between different life stages in this past population. It was difficult to draw conclusions regarding the duration of breastfeeding and timing of weaning using the stable isotope results from the Taumako neonates, infants and young children because of the variation in stable isotope values of these young individuals and the demographic profile of the sample (a lack of 3.1 to 5-year-old individuals). The foetal and neonatal individuals who were too young to display a breastfeeding signal in their bone collagen displayed high nitrogen stable isotope values compared to the adult females' mean, and it was therefore suggested that other factors, such as physiological stress from disease during pregnancy, may have influenced the nitrogen stable isotope values of all the foetal, infant and young subadults who died.

Recent studies have started questioning the validity of stable isotope values of the bone collagen of subadults because of 
the possible effect of stress on their $\delta^{13} \mathrm{C}$ and $\delta^{15} \mathrm{~N}$ values. Highresolution microsampling of tooth dentine of adults (i.e. the survivors) can help determine the possible reasons for variable $\delta^{13} \mathrm{C}$ and $\delta^{15} \mathrm{~N}$ values within a sample population (Beaumont et al. 2015). In this study, the use of bulk tooth dentine to assess the childhood diet of the adults may therefore be more representative of the true diet of these young individuals, as compared to the bone collagen values of the deceased subadults (Wood et al. 1992). Future analyses of the Taumako population will use high-resolution microsampling of tooth dentine to assess the diet and health of these individuals.

Our approach has provided insight into human behaviour, cultural processes and health at the Taumako site, such as possible culturally moderated feeding practices and labour specialization that may have affected diet, nutrition and survival. Focussing on groups that have traditionally been overlooked, especially women, infants and children, can help us understand the quality of life of all members of a past community. It is suggested that future studies may benefit from using isotopic data to help address health and disease questions in this and other samples.

Acknowledgments Open access funding provided by Max Planck Society. We would like to thank the archaeologists, Foss Leach and Janet Davidson, who excavated the Namu burial ground on Taumako during the 1970s. We are indebted to the Department of Anatomy, University of Otago, for assistance with the cost of the isotope analyses. Andrew Gray provided invaluable expertise for the statistical analyses performed in this study.

Open Access This article is distributed under the terms of the Creative Commons Attribution 4.0 International License (http:// creativecommons.org/licenses/by/4.0/), which permits unrestricted use, distribution, and reproduction in any medium, provided you give appropriate credit to the original author(s) and the source, provide a link to the Creative Commons license, and indicate if changes were made.

\section{References}

Allen MS, Craig JA (2009) Dynamics of Polynesian subsistence: insights from archaeofauna and stable isotope studies, Aitutaki, Southern Cook Islands. Pac Sci 63(4):477-506

Ambrose SH (1993) Isotopic analysis of paleodiets: methodological and interpretive considerations. In: Sandford MK (ed) Investigations of ancient human tissue: chemical analyses in anthropology. Gordon and Breach, Philadelphia, pp. 59-130

Ambrose SH, Norr L (1993) Experimental evidence for the relationship of the carbon isotope ratios of whole diet and dietary protein to those of bone collagen and carbonate. In: Lambert JB, Grupe G (eds) Prehistoric human bone: archaeology at the molecular level. Springer-Verlag, Berlin, pp. 1-37

Ambrose SH, Butler BM, Hanson DB, Hunter-Anderson RL, Krueger HW (1997) Stable isotopic analysis of human diet in the Marianas Archipelago, Western Pacific. Am J Phys Anthropol 104(3):343-361

Barrau J (1958) Subsistence agriculture in Melanesia. Bernice P. Bishop Museum, Honolulu

Barrau J (1961) Subsistence agriculture in Polynesia and Micronesia. Bernice P. Bishop Museum, Honolulu
Bashan Y, Holguin G (2002) Plant growth-promoting bacteria: a potential tool for arid mangrove reforestation. Trees 16(2):159-166

Beaumont J, Gledhill A, Lee-Thorp J, Montgomery J (2013) Childhood diet : a closer examination of the evidence from dental tissues using stable isotope analysis of incremental human dentine. Archaeometry 55:277-295

Beaumont J, Montgomery J, Buckberry J, Jay M (2015) Infant mortality and isotopic complexity: new approaches to stress, maternal health, and weaning. Am J Phys Anthropol 157:441-457

Bedford S, Spriggs M, Buckley H, Valentin F, Regenvanu R, Abong M (2010) A cemetery of first settlement: the site of Teouma, South Efate, Vanuatu. In: Bedford S (ed) Sand C. Lapita, Oceanic Ancestors, pp. p141-p161

Bedford S, Buckley H, Valentin F, Tayles N, Longga NF (2011) Lapita burials, a new Lapita cemetery and post-Lapita burials from Malakula, Northern Vanuatu, Southwest Pacific. J Pac Archaeol 2(2):26-48

Bocherens H, Drucker D (2003) Trophic level isotopic enrichment of carbon and nitrogen in bone collagen: case studies from recent and ancient terrestrial ecosystems. Int J Osteoarchaeol 13(1-2):46-53

Bogaard A, Heaton THE, Poulton P, Merbach I (2007) The impact of manuring on nitrogen isotope ratios in cereals: archaeological implications for reconstruction of diet and crop management practices. $\mathrm{J}$ Archaeol Sci 34:335-343

Brown TA, Nelson DE, Vogel JS, Southon JR (1988) Improved collagen extraction by modified Longin method. Radiocarbon 30(2):171-177

Buckley HR (2001) Health and disease in the prehistoric Pacific Islands [PhD]. University of Otago, Dunedin

Buckley HR (2006) 'The predators within': investigating the relationship between malaria and health in the prehistoric Pacific Islands. In: Oxenham MF, Tayles N (eds) Bioarchaeology of Southeast Asia. Cambridge University Press, Cambridge, pp. 309-332

Buckley HR (2007) Possible gouty arthritis in Lapita-associated skeletons from Teouma, Efate Island, Central Vanuatu. Curr Anthropol 48(5): 741-749

Buckley H. (2016) Health and disease in the prehistoric Pacific Islands. Oxford. British Archaeological Reports International Series 2792. Oxford: British Archaeological Reports Ltd

Buckley HR, Dias GJ (2002) The distribution of skeletal lesions in treponemal disease: is the lymphatic system responsible? Int $\mathrm{J}$ Osteoarchaeol 12(3):178-188

Buckley H, Oxenham M (2016) Bioarchaeology in the Pacific Islands: a temporal and geographical examination of nutritional and infectious disease. In: Oxenham M, Buckley H (eds) The Routledge Handbook of Bioarchaeology in Southeast Asia and the Pacific. Routledge, London, pp. 363-388

Buckley HR, Tayles N (2003a) The functional cost of tertiary yaws (Treponema pertenue) in a prehistoric Pacific Island skeletal sample. J Archaeol Sci 30(10):1301-1314

Buckley HR, Tayles N (2003b) Skeletal pathology in a prehistoric Pacific Island sample: issues in lesion recording, quantification, and interpretation. Am J Phys Anthropol 122(4):303-324

Buckley HR, Tayles N, Spriggs M, Bedford S (2008) A preliminary report on health and disease in Early Lapita skeletons, Vanuatu: possible biological costs of island colonisation. J Island Coast Archaeo 3:87-114

Buckley HR, Tayles N, Halcrow SE, Robb KF, Fyfe R (2010) The people of Wairau Bar: a re-examinaion. J Pac Archaeol 1:1-20

Buckley H, Kinaston R, Halcrow SE, Foster A, Spriggs M, Bedford S (2014) Scurvy in a tropical paradise? Evaluating the possibility of infant and adult vitamin $\mathrm{C}$ deficiency in the Lapita skeletal sample of Teouma, Vanuatu, Pacific islands. International Journal of Paleopathology 5:72-85

Buikstra JE, Ubelaker DH (1994) Standards for data collection from human skeletal remains. Arkansas Archaeological Survey, Fayetteville 
Collins MJ, Galley P (1998) Towards an optimal method of archaeological collagen extraction: the influence of $\mathrm{pH}$ and grinding. Anc Biomol 2:209-222

Commendador AS, Dudgeon JV, Finney BP, Fuller BT, K.S. E (2013) A stable isotope $\left(\delta^{13} \mathrm{C}\right.$ and $\left.\delta^{15} \mathrm{~N}\right)$ perspective on human diet on Rapa Nui (Easter Island) ca. AD 1400-1900. Am J Phys Anthropol 152: 173-185

Davidson JM, Leach BF (1991) Bird-man amulets and Tridacna shell discs from Taumako, Solomon Islands. In: Pawley A (ed) Man and a half: essays in Pacific anthropology and ethnobiology in honour of Ralph Bulmer. Auckland The Polynesian Society, pp. 478483

Davidson J, Leach F (2001) The Strandlooper concept and economic naivety. In: Clark GR, Anderson AJ, Sorovi-Vunidilo T (eds) The archaeology of Lapita dispersal in Oceania, Terra Australis 17. Pandanus Books, Canberra, pp. 115-123

de Luca A, Boisseau N, Tea I, Louvet I, Robins RJ, Forhan A, Charles MA, Hankard R (2012) $\delta^{15} \mathrm{~N}$ and $\delta^{13} \mathrm{C}$ in hair from newborn infants and their mothers:a cohort study. Pediatr Res 71:598-604

DeNiro MJ (1985) Postmortem preservation and alteration of in vivo bone collagen isotope ratios in relation to palaeodietary reconstruction. Nature 317(6040):806-809

DeNiro MJ, Epstein S (1978) Influence of diet on the distribution of carbon isotopes in animals. Geochim Cosmochim Ac 42(5):495-506

DeNiro MJ, Epstein S (1981) Influence of diet on the distribution of nitrogen isotopes in animals. Geochim Cosmochim Ac 45(3):341-351

Douglas MT, Pietrusewsky M, Ikehara-Quebral RM (1997) Skeletal biology of Apurguan: a precontact Chamorro Site on Guam. Am J Phys Anthropol 104:291-313

Field JS, Cochrane EE, Greenlee DM (2009) Dietary change in Fijian prehistory: isotopic analyses of human and animal skeletal material. J Archaeol Sci 36(7):1547-1556

Fogel ML, Tuross N, Owsley DW (1989) Nitrogen isotope tracers of human lactation in modern and archaeological populations. Annual report of the director, geophysical laboratory, Carnegie Institution of Washington 1988-1989. Carnegie Institution of Washington, Washington D.C, pp. 111-117

Fraser KL, Bogaard A, Heaton T, Charles M, Jones G, Christiansen BT (2011) Manuring and stable nitrogen isotope ratios in cereals and pulses: towards a new archaeobotanical approach to the inference of land use and dietary practices. J Archaeol Sci 38:2790-2804

Froehle AW, Kellner CM, Schoeninger MJ (2010) FOCUS: effect of diet and protein source on carbon stable isotope ratios in collagen: follow up to Warinner and Tuross (2009). J Archaeol Sci 37(10):2662-2670

Fuller BT, Richards MP, Mays SA (2003) Stable carbon and nitrogen isotope variations in tooth dentine serial sections from Wharram Percy. J Archaeol Sci 30(12):1673-1684

Fuller BT, Fuller JL, Harris DA, Hedges REM (2006a) Detection of breastfeeding and weaning in modern human infants with carbon and nitrogen stable isotope ratios. Am J Phys Anthropol 129:279-293

Fuller BT, Molleson TI, Harris DA, Gilmour LT, Hedges REM (2006b) Isotopic evidence for breastfeeding and possible adult dietary differences from Late/Sub-Roman Britain. Am J Phys Anthropol 129(1): $45-54$

Gowland R, Western A (2012) Morbidity in the marshes: using spatial epidemiology to investigate skeletal evidence for malaria in AngloSaxon England (AD 410-1050). Am J Phys Anthropol 147:301-311

Heaton THE, Vogel JC, von la Chevallerie G, Collett G (1986) Climatic influence on the isotopic composition of bone nitrogen. Nature 322: $822-823$

Hedges REM, Reynard LM (2007) Nitrogen isotopes and the trophic level of humans in archaeology. J Archaeol Sci 34(8):1240-1251

Hedges REM, Clement JG, Thomas CDL, O'Connell TC (2007) Collagen turnover in the adult femoral mid-shaft: modeled from anthropogenic radiocarbon tracer measurements. Am J Phys Anthropol 133:808-816
Hendrickse R (1987) Malaria and child health. Ann Trop Med Parasitol 81(5):499-509

Jacobi RM, Higham TFG, Bronk RC (2006) AMS radiocarbon dating of Middle and Upper Palaeolithic bone in the British Isles: improved reliability using ultrafiltration. J Quat Sci 21(5):557-573

Jay M (2009) Breastfeeding and weaning behaviour in archaeological populations: evidence from the isotopic analysis of skeletal materials. Childhood in the Past 2:165-181

Jay M, Fuller BT, Richards MP, Knüsel CJ, King SS (2008) Iron Age breastfeeding practices in Britain: isotopic evidence from Wetwang Slack, East Yorkshire. Am J Phys Anthropol 136:327-337

Jim S, Ambrose SH, Evershed RP (2004) Stable carbon isotopic evidence for differences in the dietary origin of bone cholesterol, collagen and apatite: implications for their use in palaeodietary reconstruction. Geochim Cosmochim Ac 68(1):61-72

Jones S, Quinn RL (2009) Prehistoric Fijian diet and subsistence: integration of faunal, ethnographic, and stable isotopic evidence from the Lau Island Group. J Archaeol Sci 36:2742-2754

Katzenberg MA (1999) A re-examination of factors contributing to elevated stable nitrogen isotopes values in infants and young children (abstract). Am J Phys Anthropol (Supplement) 28:165

Katzenberg MA (2008) Stable isotope analysis: a tool for studying past diet, demography, and life history. In: Katzenberg MA, Saunders S (eds) Biological anthropology of the human skeleton. Wiley-Liss, Hoboken, New Jersey, pp. 413-441

Katzenberg MA, Lovell NC (1999) Stable isotope variation in pathological bone. Int J Osteoarchaeol 9(5):316-324

Katzenberg MA, Herring DA, Saunders SR (1996) Weaning and infant mortality: evaluating the skeletal evidence. Yeab Phys Anthropol 39:177-199

Keegan WF, DeNiro MJ (1988) Stable carbon and nitrogen isotope ratios of bone collagen used to study coral reef and terrestrial components of prehistoric Bahamian diet. Am Antiquity 53(2):320-336

Kellner CM, Schoeninger MJ (2007) A simple carbon isotope model for reconstructing prehistoric human diet. Am J Phys Anthropol 133(4): $1112-1127$

Kinaston RL, Buckley HR (2013) Lapita and later prehistoric diet in the Pacific islands using stable isotope analysis. In: Summerhayes G, Buckley HR (eds) Pacific archaeology: documenting the past 50,000 years. University of Otago Press, Dunedin, pp. 91-107

Kinaston RL, Buckley HR, Halcrow SE, Spriggs MJT, Bedford S, Neal K, Gray A (2009) Investigating foetal and perinatal mortality in prehistoric skeletal samples: a case study from a 3000-year-old Pacific Island cemetery site. J Archaeol Sci 36:2780-2787

Kinaston RL, Buckley HR, Gray A (2013a) Diet and social status on Taumako, a Polynesian outlier in the Southeastern Solomon Islands. Am J Phys Anthropol 151:589-603

Kinaston RL, Buckley HR, Gray A, Shaw B, Mandui H (2013b) Exploring subsistence and cultural complexes on the south coast of Papua New Guinea using palaeodietary analyses. J Archaeol Sci 40(2):904-913

Kinaston RL, Walter R, Jacomb C, Brooks E, Tayles N, Halcrow SE, Stirling C, Reid M, Gray A, Spinks J et al (2013c) The first New Zealanders: patterns of diet and mobility revealed through isotope analysis. PLoS One 8(5):e64580

Kinaston RL, Bedford S, Richards M, Hawkins S, Gray A, Jaouen K, Valentin F, Buckley H (2014a) Diet and human mobility from the Lapita to the early historic periods on Uripiv Island, Northeast Malakula, Vanuatu. PLoS One 9(8):e104071

Kinaston RL, Buckley HR, Valentin F, Bedford S, Spriggs M, Hawkins S, Herrscher E (2014b) Lapita diet in remote Oceania: new stable isotope evidence from the 3000-year-old Teouma site, Efate Island, Vanuatu. PLoS One 9(3):e90376

Kinaston R, Bedford S, Spriggs M, Buckley H (2016a) Is there a 'Lapita diet'? A comparison of Lapita and post-Lapita skeletal samples from four Pacific island archaeological sites. In: Oxenham M, Buckley H 
(eds) The Routledge Handbook of Bioarchaeology in Southeast Asia and the Pacific. Routledge, London, pp. 427-461

Kinaston R, Roberts GL, Buckley H, Oxenham MF (2016b) A bioarchaeological analysis of diet and health on the south coast of New Guinea. Am J Phys Anthropol 160:414-426

Kirch PV (1984) The Polynesian outliers: continuity, change, and replacement. J Pac Hist 19:224-238

Kirch PV (1997) The Lapita peoples: ancestors of the oceanic world. Blackwell, Oxford

Kirch PV (2002) Te Kai Paka-Anuta: food in a Polynesian outlier society. Journal de la Societe des Oceanistes 114-115:71-89

Leach BF, Davidson J (2008) Archaeology on Taumako: a Polynesian outlier in the Eastern Solomon Islands. New Zealand Journal of Archaeology, Dunedin

Leach BF, Quinn CJ, Lyon GL (1996) A stochastic approach to the reconstruction of prehistoric human diet in the Pacific region from bone isotope signatures. Tuhinga: Records of the Museum of New Zealand Te Papa Tongarewa 8:1-54

Leach BF, Quinn CJ, Lyon GL, Haystead A, Myers DB (2000) Evidence of prehistoric Lapita diet at Watom Island, Papua New Guinea, using stable isotopes. New Zeal J Archaeol 20:149-159

Leach BF, Quinn CJ, Morrison J, Lyon GL (2003) The use of multiple isotope signatures in reconstructing prehistoric human diet from archaeological bone from the Pacific and New Zealand. New Zeal J Archaeol 23:31-98

Lewis ME (2007) The Bioarchaeology of children: perspectives from biological and forensic anthropology. Cambridge University Press, Cambridge

Littleton J, Kinaston R (2008) Ancestry, age, sex and stature: identification in a diverse space. In: Oxenham MF (ed) Forensic approaches to death disaster and abuse. Australian Academic Press, Canberra, pp. 155-176

Longin R (1971) New method of collagen extraction for radiocarbon dating. Nature 230(5291):241-242

Minagawa M, Wada E (1984) Stepwise enrichment of ${ }^{15} \mathrm{~N}$ along food chains: further evidence and the relation between $\delta^{15} \mathrm{~N}$ and animal age. Geochim Cosmochim Ac 48(5):1135-1140

Moorrees CFA, Fanning EA, Hunt EEJ (1963a) Age variation for formation stages for ten permanent teeth. J Dent Res 42:1490-1502

Moorrees CFA, Fanning EA, Hunt EEJ (1963b) Formation and resorption of three deciduous teeth in children. Am J Phys Anthropol 21:205-213

Müldner G, Richards MP (2007) Stable isotope evidence for 1500 years of human diet at the city of York, UK. Am J Phys Anthropol 133:682-697

Nitsch EK, Humphrey LT, Hedges REM (2011) Using stable isotope analysis to examine the effect of economic change on breastfeeding practices in Spitalfields, London, UK. Am J Phys Anthropol 146:619-628

Oomen H, and Malcolm SH. (1958) Nutrition and the Papuan child: a study in human welfare. Noumea, New Caledonia: South Pacific Commission, Technical Paper No. 118

Pate FD, Anson TJ (2008) Stable nitrogen isotope values in arid-land kangaroos correlated with mean annual rainfall: potential as a palaeoclimatic indicator. Int J Osteoarchaeol 18(3):317-326

Pate FD, Craib JL, Heathcote GM (2001) Stable isotopic analysis of prehistoric human diet in the Mariana Islands, western Pacific. Aust Archaeol 52:1-4

Pietrusewsky M (2005) The physical anthropology of the Pacific, East Asia and Southeast Asia. In: Sargat L, Blench R, Sanchex-Mazas A (eds) The peopling of East Asia: putting together archaeology, linguistics and genetics. Routledge Curzon, London, pp. 203-231

Pietrusewsky M (2006) The initial settlement of remote Oceania: the evidence from physical anthropology. In: Simanjuntak T, Pojoh IHE, Hisyam M (eds) Austronesian diaspora and the ethnogenesis of people in Indonesian Archipelago Proceedings of the International Symposium. Indonesian Institute of Sciences, LIPI Press, Jakarta, pp. 320-347
Pietrusewsky M, Douglas MT, Ikehara-Quebral RM (1997) An assessment of health and disease in the prehistoric inhabitants of the Mariana Islands. Am J Phys Anthropol 104(3):315-342

Prowse TL, Saunders SR, Schwarcz HP, Garnsey P, Macchiarelli R, Bondioli L (2008) Isotopic and dental evidence for infant and young child feeding practices in an imperial Roman skeletal sample. Am J Phys Anthropol 137:294-308

Richards MP, Hedges REM (1999) Stable isotope evidence for similarities in the types of marine foods used by Late Mesolithic humans at sites along the Atlantic Coast of Europe. J Archaeol Sci 26:717-722

Richards MP, West E, Rolett B, Dobney K (2009) Isotope analysis of human and animal diets from the Hanamiai archaeological site (French Polynesia). Archaeol Ocean 44:29-37

Schoeninger MJ, DeNiro MJ (1984) Nitrogen and carbon isotopic composition of bone collagen from marine and terrestrial animals. Geochim Cosmochim Ac 48(4):625-639

Schwarcz HP (1991) Some theoretical aspects of isotope paleodiet studies. J Archaeol Sci 18(3):261-276

Schwarcz HP, Dupras TL, Fairgrieve SI (1999) $15 \mathrm{~N}$ enrichment in the Sahara: in search of a global relationship. J Archaeol Sci 26(6):629-636

Sheppard P, Pavlish LA (1992) Weathering of archaeological cherts: a case study from the Solomon Islands. Geoarchaeology 7:41-53

Smith BH (1991) Standards of human tooth formation and dental age assessment. In: Kelley MA, Larsen CS (eds) Advances in dental anthropology. Wiley-Liss, New York, pp. 143-168

Spriggs M (1997) The island Melanesians: the peoples of South-East Asia and the Pacific. Blackwell, Cornwall

Stantis C, Kinaston RL, Richards M, Davidson J, Buckley H (2015) Assessing human diet and movement in the Tongan Maritime Chiefdom using isotopic analyses. PLoS One 10(3):e0123156

Stantis C, Buckley H, Kinaston RL, Nunn P, Jaouen K, Richards MP (2016a) Isotopic evidence of past human mobility and diet Fijian site of Bourewa (c. 750-150 BP). Am J Phys Anthropol 159(3): 478-495

Stantis C, Tayles N, Kinaston R, Cameron C, Nunn PD, Richards MP, Buckley H (2016b) Diet and subsistence in Remote Oceania: an analysis using oral indicators of diet. In: Oxenham M, Buckley $\mathrm{H}$ (eds) The Routledge Handbook of Bioarchaeology in Southeast Asia and the Pacific. Routledge, London, pp. 569-598

Stodder ALW, Ryan EM, Hunter-Anderson RL, Toomay Douglas MB, Ikehara-Quebral R (2016) Under the latte: osteobiography and social context of a burial assemblage at Tumon Bay, Guam. In: Oxenham M, Buckley H (eds) The Routledge Handbook of Bioarchaeology in Southeast Asia and the Pacific. Routledge, London, pp. 527-568

Storey AA, Ramírez JM, Quiroz D, Burley DV, Addison DJ, Walter R, Anderson AJ, Hunt TL, Athens JS, Huynen L et al (2007) Radiocarbon and DNA evidence for a pre-Columbian introduction of Polynesian chickens to Chile. Proc Natl Acad Sci 104(25): 10335-10339

Summerhayes GR (2001) Defining the chronology of Lapita in the Bismarck Archipelago. In: Clark GR, Anderson AJ, SoroviVunidilo T (eds) The archaeology of Lapita dispersal in Oceania, Terra Australis 17. Pandanus Books, Canberra, pp. 25-38

Summerhayes G, Leavesley M, Fairbairn A, Mandui H, Field J, Ford A, Fullagar R (2010) Human adaptation and plant use in Highland New Guinea 49,000 to 44,000 years ago. Science $330: 78-80$

Tieszen LL, Fagre T (1993) Effect of diet quality and composition on the isotopic composition of respiratory $\mathrm{CO}_{2}$, bone collagen, bioapatite, and soft tissues. In: Lambert JB, Grupe G (eds) Prehistoric human bone: archaeology at the molecular level. Springer, Berlin, pp. 121155

Tsutaya T, Yoneda M (2015) Reconstruction of breastfeeding and weaning practices using stable isotope and trace element analyses: a review. Yeab Phys Anthropol 156:2-21 
Turner BL, Edwards JL, Quinn EA, Kingston JD, Van Gerven DP (2007) Age-related variation in isotopic indicators of diet at Medieval Kulubnarti, Sudanese Nubia. Int J Osteoarchaeol 17:1-25

Turner-Walker G (2008) The chemical and microbial degradation of bones and teeth. In: Mays S (ed) Pinhasi R. Wiley., Advances in Human Paleopathology, pp. 3-29

Ubelaker DH (1989) The estimation of age at death from immature human bone. In: Iscan MY (ed) Age markers in the human skeleton. Springfield, Charles C Thomas, pp. 55-70

Valentin F, Bocherens H, Gratuze B, Sand C (2006) Dietary patterns during the late prehistoric/historic period in Cikobia island (Fiji): insights from stable isotopes and dental pathologies. J Archaeol Sci 33(10):1396-1410

Valentin F, Herrscher E, Petchey F, Addison DJ (2011) An analysis of the last 1000 years human diet on Tutuila (American Samoa) using carbon and nitrogen stable isotope data. Am Antiquity 76(3):473-486

Valentin F, Herrscher E, Bedford S, Spriggs M, Buckley H (2014) Evidence for social and cultural change in central Vanuatu between 3000 and 2000 BP: comparing funerary and dietary patterns of the first and later generations at Teouma, Efate. J Island Coast Archaeo 9:381-399

van Klinken GJ (1999) Bone collagen quality indicators for palaeodietary and radiocarbon measurements. J Archaeol Sci 26(6):687-695

Waldron T (1994) Counting the dead: the epidemiology of skeletal populations. Wiley, Chichester

Waters-Rist AL, Katzenberg MA (2010) The effect of growth on stable nitrogen isotope ratios in subadult bone collagen. Int $\mathrm{J}$ Osteoarchaeol 20:172-191

White CD, Armelagos GJ (1997) Osteopenia and stable isotope ratios in bone collagen of Nubian female mummies. Am J Phys Anthropol 103(2): 185-199

Wood JW, Milner GR, Harpending HC, Weiss KM (1992) The osteological paradox: problems of inferring prehistoric health from skeletal samples. Curr Anthropol 33(4):343-370

Yamamuro M, Kayanne H, Minagawa M (1995) Carbon and nitrogen stable isotopes of primary producers in coral reef ecosystems. Limnol Oceanogr 40(3):617-621 